\title{
NORSK KRONIKK*
}

Av professor dR. JURIS AsbJøRn StrandBAKKEN

\section{Innledning}

$\AA$ redegjøre for temaet «Norsk kriminalpolitikk anno 2003» er ingen enkel oppgave. Det har riktignok ikke manglet på kriminalpolitiske dokumenter gjennom 1990-årene, men det har ikke foreligget noen helhetlig kriminalpolitikk. Siden tusenårsskiftet har det blitt vedtatt en rekke endringer i straffeloven. Det er ingen tvil om at dokumentene som ligger til grunn for lovendringene samlet kan gi et inntrykk av norsk kriminalpolitikk anno 2003. Men signalene er langt fra entydige. På den ene siden er det for mange straffbare forhold krevd strengere straffer, mens det på den andre siden er åpnet opp for mer individual orienterte reaksjoner som samfunnsstraff $m v^{2}$

I 2002 ble det fremlagt forslag til ny straffelov, jfr. NOU 2002: 4 Straffelovkommisjonens delutredning VII. ${ }^{3}$ Straffelovgivningen er mao. i støpeskjeen, og forslaget fra 2002 vil danne utgangspunkt for den kriminalpolitiske debatten i Norge ikke bare i 2003, men også i årene fremover til det blir vedtatt en ny straffelov. Fremfor å fremstille norsk kriminalpolitikk anno 2003 gjennom å vurdere de politiske signaler som kan variere fra dag til dag, har jeg valgt å presentere og vurdere Straffelovkommisjonens utredning. ${ }^{4}$

\section{Om lovgivningsarbeidet}

\subsection{Straffelovkommisjonen oppnevnes}

Straffelovkommisjonen ble oppnevnt 26. september 1980. Oppnevningen hadde sin bakgrunn i St.meld. nr. 104 (1977-78) Om kriminalpolitikken. Justisdepartementet anførte den gang at det «selvfølgelig [skulle] spesielle grunner til for nå å sette i verk en fullstendig straffelovsreform»». ${ }^{5}$ Et slikt arbeid måtte være begrunnet $i$ at man kunne vise til raske endringer i samfunnet eller mer langsiktige endringer som hadde fjernet loven fra samfunnsforholdene, slik at en løpende revisjon ikke kunne anses som hensiktsmessig. Departementet pekte på at straffeloven av 1902 på dette tidspunktet nærmet seg 75 år, og at gjeldende lov hadde avløst kriminalloven fra 1842 etter bare 60 år. ${ }^{6}$ Alderen var imidlertid ikke avgjørende, men:

«... Hovedsaken er den samfunnsutvikling som har funnet sted i vårt land siden århundreskiftet. ...» St.meld. nr. 104 (1977-78) s. 96 første spalte.

\footnotetext{
* Kronikken bygger på et foredrag i Högre seminarium i straffrätt, Juridiska fakulteten i Uppsala, 13. februar 2003 som hadde tittelen «Norsk kriminalpolitikk anno 2003». Jeg takker professor Nils Jareborg for å ha invitert meg til å foredra om dette emnet som nå presenteres som kronikk i NTfK.
} 
Departementet mente at de grunnleggende målsetningene i kriminalmeldingen krevde en ny straffelov. ${ }^{7}$ Det ble vist til at fellesskapets problemer inntok en helt annen plass i 1978 enn da straffeloven ble gitt. Miljøvernproblemer var nærmest ukjent i 1902, og biltrafikken var helt ukjent. Det var de økonomiske forbrytelser ved angrep på individuelle formuesgoder som var dominerende da straffeloven ble vedtatt, mens det 75 år senere var naturlig å fokusere mer på angrep på økonomiske fellesgoder i form av skatte- og avgiftsunndragelser. ${ }^{8}$

Videre anførte departementet at straffeloven ikke bare skulle være et middel til å møte uønskede handlinger, men den ga også uttrykk for hvordan samfunnet vurderte graden av straffverdighet av ulike typer handlinger. Når flere, mindre vinningsforbrytelser ble møtt med streng straff, mens omfattende skatteunddragelser ble møtt med tilleggsskatt, ville dette også kunne oppfattes som samfunnets vurdering av det innbyrdes forhold mellom handlingene. Endringer i straffereaksjonene kunne bidra til holdningsendringer, mens opprettholdelse av de etablerte rammer kunne virke konserverende på vurderingen av hva som var særlig straffverdig i samfunnet. Dertil var straffereaksjonene etter spesiallovgivningen gjerne mer lempelig enn straffereaksjonene i straffeloven, og moderne kriminalitet ble gjerne stilt gunstigere enn tradisjonell kriminalitet. ${ }^{9}$ Etter departementets mening måtte det derfor foretas en:

\footnotetext{
«... nyvurdering av den tradisjonelle straffelovgivning i forhold til strafferettslige reaksjoner i spesiallovgivningen ... Med utgangspunkt i de interesser som skal beskyttes av vår samlede straffelovgivning eksisterer det i dag en klar ubalanse, idet så mye av samfunnets kamp mot kriminalitet settes inn for å gjøre opp konflikter mellom enkeltmennesker etter straffeloven fra 1902. Dette må fortsatt ha stor vekt, men samfunnsinteresser som springer ut av senere tids utvikling og nyere lovgivning må samtidig få en sterkere beskyttelse.» St.meld. nr. 104 (1977-78) s. 97 andre spalte.
}

Justisdepartementet forutsatte at å utforme en ny straffelov ville være en tidkrevende oppgave. Det ble derfor understreket at reformen ikke skulle erstatte den fortløpende revisjon og endring av straffelovgivningen som det til enhver tid viste seg å være behov for. Fra oppnevnelsen av Straffelovkommisjonen har derfor bl.a. Straffelovrådet - som er et fast utvalg oppnevnt i 1947 - fortløpende arbeidet med konkrete, mindre revisjoner av straffelovgivningen.

Straffelovkommisjonen fikk i 1980 følgende medlemmer: professor Anders Bratholm (formann), advokat Regine Ramm Bjerke, riksadvokat Magnar Flornes, forskningssjef Ragnar Hauge, ekspedisjonssjef Georg Frederik RieberMohn, høyesterettsdommer Helge Røstad og komitesekretær Rakel Surlien. Røstad trådte ut av kommisjonen i 1982, men fortsatte som rådgiver for den. ${ }^{10}$

\subsection{Straffelovkommisjonens delutredning I-NOU 1983: 57 Straffelovgivningen under omforming}

Straffelovkommisjonens første delutredning ble fremlagt 4. november 1983. 
Den inneholder kommisjonens foreløpige synspunkter på viktige reformspørsmål. Kommisjonen forutsatte at utredningen ble sendt på høring slik at man fikk et best mulig grunnlag for det videre arbeidet. ${ }^{11}$

Kommisjonen fremhevet at straffeloven av 1902 hadde vært gjenstand for mange endringer siden vedtakelsen. Men:

\begin{abstract}
«Selv om den løpende reformvirksomheten har ført til at vår straffelov stort sett ikke fremstår som en utjenlig lov, er det likevel behov for en samlet gjennomgåelse av loven. Det er f eks behov for å vurdere hvilke straffebud som i dagens samfunn må anses som foreldet, og hvilke som har en strafferamme som ikke lenger svarer til det rådende verdisyn. De mange delrevisjoner har heller ikke gitt anledning til en mer grundig gjennomtenkning av f eks straffelovens systematikk og grunnbegreper. Det er også behov for å se nærmere på forholdet mellom straffeloven og det store antall straffebud $i$ andre lover. For eksempel kan enkelte av dem være så viktige at de bør tas inn i den nye straffeloven, mens andre mer naturlig hører hjemme i en særlov.

De mange delrevisjoner har i tidens løp ført til at språket i straffeloven er lite enhetlig. Iblant er også uttrykksmåten så gammelmodig at loven kan være vanskelig å forstå.» NOU 1983: 57 s. 16 første spalte.
\end{abstract}

Standpunktene i delutredning I har fått stor betydning for det videre reformarbeidet. Noen forslag til endringer ble imidlertid ansett som så påkrevd at de burde gjennomføres før den totale revisjonen av straffeloven kunne gjennomføres. Blant annet fremhevet kommisjonen behovet for å heve den kriminelle lavalder fra 14 til 15 år, og å senke minstestraffen fra 21 til 14 dager. Senkingen av minstestraffen ble gjennomført ved lov av 12. april $1985 \mathrm{nr} .18 .{ }^{12}$ Hevingen av den kriminelle lavalder ble foretatt ved lov av 12. juni $1987 \mathrm{nr}$. 51, men trådte først i kraft fra 1. januar 1990, jfr. lov av 16. juni 1989 nr. 66. Av straffeprosessuelle endringer som ble foreslått gjennomført før den totale revisjonen av straffeloven, nevnes lovfesting av klageretten over påtalevedtak som ble vedtatt ved lov av 19. juli $1996 \mathrm{nr}$. 58, se strpl. $\S 59$ a. ${ }^{13}$

\title{
2.3. Straffelovkommisjonens delutredning II - NOU 1984: 31 Straffelovgivnin- gens stedlige virkeområde
}

Den 28. mars 1984 fremla et underutvalg under Straffelovkommisjonen en utredning hvor det ble foreslått en omstrukturering av straffelovens regler om stedlige virkeområde, samt visse mindre endringer av dem. Utredningen ledet ikke frem til noen umiddelbar lovendring, og utkastet til ny alminnelig del fra 1991 avviker på flere punkter fra det som ble foreslått av utvalget. ${ }^{14}$ Reglene om straffelovens stedlige virkeområdet har for øvrig blitt endret en rekke ganger siden kommisjonen fremla sitt utkast til alminnelige del i $1991 .{ }^{15}$

\subsection{Straffelovkommisjonens delutredning III - NOU 1989: 11 Straffansvar for foretak}

Straffelovkommisjonen fremla 13. mars 1989 forslag til regler om straffansvar 
for foretak. Mindretallet i kommisjonen foreslo at det i straffelovens alminnelig del ble inntatt en generell bestemmelse som ga hjemmel for å ilegge foretaksstraff. Flertallet ville imidlertid at straffeloven bare skulle inneholde fellesvilkårene for foretaksstraff, slik at hjemmelen for foretaksstraff måtte fastsettes i det enkelte straffebud. Dersom det ikke forelå en slik hjemmel, skulle det ikke være grunnlag for å ilegge straff. ${ }^{16}$

Utredningen ledet frem til at det i samsvar med mindretallets standpunkt ble vedtatt en generell hjemmel for foretaksstraff i strl. $\S 48$ a, jfr. lov av 20. juli $1991 \mathrm{nr} .66 .{ }^{17}$ Bestemmelsen er videreført i utkastet til ny straffelov av 1991 $\S 35,{ }^{18}$ mens kommisjonen av 1994 har - med noen mindre språklige justeringer - foreslått tilsvarende bestemmelse i § 4-1 i utkastet fra 2002. ${ }^{19}$

\subsection{Straffelovkommisjonens delutredning IV - NOU 1990: 5 Strafferettslige} utilregnelighetsregler og sarreaksjoner

Et underutvalg under Straffelovkommisjonen - Særreaksjonsutvalget - fremla 27. september 1989 forslag til endringer i straffelovens regler om tilregnelighet og særreaksjoner. Utvalget tok utgangspunkt i et forslag fra Straffelovrådet fra 1973, jfr. NOU 1974: 17. Straffelovrådets forslag hadde i sin tid fått så sterk kritikk at det ikke hadde ledet til noe forslag om lovendring. ${ }^{20}$ Særreaksjonsutvalgets forslag avvek imidlertid på flere punkter fra Straffelovrådets forslag. Utvalget foreslo en omredigering av strl. § 44 slik at straffriheten for henholdsvis den psykotiske og den som var høygradig psykisk utviklingshemmet ble regulert $\mathrm{i}$ hvert sitt ledd av bestemmelsen. Videre ble det foreslått en fakultativ straffrihetsregel for den som handlet i en alvorlig psykisk avvikstilstand uten at han oppfylte kravene etter strl. $\S 44 .^{21}$ For personer som pga. av utilregnelighet ble fritatt for straff, og som ble ansett som farlige, ble det foreslått å oppheve det såkalte sikringsinstituttet og erstatte det med dom på overføring til tvungent psykisk helsevern. ${ }^{22}$ Også for tilregnelige, men farlige gjerningspersoner, foreslo utvalget å oppheve sikringsinstituttet. I stedet skulle man kunne idømme straff $i$ form av forvaring. ${ }^{23}$

Særreaksjonsutvalgets utredning ble lagt til grunn for departementets forslag til nye regler om særreaksjoner som ble vedtatt ved lov av 17. januar $1997 \mathrm{nr}$. $11 . .^{24}$ Med unntak av forslaget om en fakultativ straffritaksregel, fikk dette tilslutning av flertallet i Justiskomiteen. ${ }^{25}$ Lovendringen trådte først i kraft 1. januar 2002, jfr. lov av 15. juni $2001 \mathrm{nr}$. $65 .^{26} \mathrm{I}$ tilknytning til ikrafttredelsen, ble det foretatt visse justeringer av reglene slik de lød etter endringen i $1997 .{ }^{27}$

\subsection{Straffelovkommisjonens delutredning V-NOU 1992: 23 Ny straffelov - alminnelige bestemmelser}

Forslag til en ny straffelovs alminnelig del, ble fremlagt 25. november 1991. Straffelovkommisjonen foreslo at man burde vedta en ny alminnelig del før arbeidet med å fremlegge forslag til den spesielle del kunne gjennomføres. Det 
ble anført at det foreliggende forslag var mer tidsmessig, samtidig som en samlet behandling av en fullstendig ny straffelov ville medføre en stor oppgave for så vel høringsinstanser som departementet. ${ }^{28}$ Forslaget ble imidlertid ikke fulgt opp av departementet. ${ }^{29}$

På tidspunktet for fremleggelsen av utkastet til alminnelig del hadde Straffelovkommisjonen etter flere utskiftninger følgende medlemmer: ${ }^{30}$ professor Anders Bratholm, advokat Regine Ramm Bjerke, førstestatsadvokat Anstein Gjengedal, professor Ragnar Hauge, høyesterettsdommer Rolv Hellesylt samt herredsrettsdommer og professor II Magnus Matningsdal. Etter at utredningen var fremlagt, ba kommisjonens formann og de fleste daværende medlemmer om å bli avløst i arbeidet med den spesielle del. Den 9. februar 1994 ble det derfor oppnevnt en ny kommisjon ledet av førstestatsadvokat Einar Høgetveit. De øvrige medlemmer var statsadvokat Ingunn Fossgard, professor Ragnar Hauge, byrettsdommer Anne Lise Rønneberg og advokat Frode Sulland. Rønneberg ble i 1997 erstattet av høyesterettsdommer Kirsti Coward. ${ }^{31}$

\subsection{Straffelovkommisjonens delutredning VI-NOU 1997: 23 Seksuallovbrudd} Seksuallovbruddsutvalget som var oppnevnt som et underutvalg under Straffelovkommisjonen, fremla 11. juli 1997 forslag til nytt kapittel 19 om seksuallovbrudd i straffeloven. Forslaget representerte for det første en språklig modernisering og forenkling av de aktuelle bestemmelsene, men det ble også foreslått materielle endringer i straffebudene.

Et flertall foreslo å nedsette den seksuelle lavalder fra 16 til 15 år. Mandatet forutsatte også at man skulle vurdere å kriminalisere grovt uaktsom voldtekt, men et flertall i utvalget frarådet dette. Bestemmelsen om hallikvirksomhet ble videreført, men for øvrig fant utvalget det uaktuelt å kriminalisere prostitusjon. Utvalget vurderte om det skulle gis en straffebestemmelse rettet mot den som kjøpte seksuelle tjenester av personer under 18 år, men fant at et slikt straffebud kunne ha uønskede og utilsiktede virkninger. For øvrig ble det foreslått å liberalisere pornografibestemmelsen slik at den bare rammet skildringer hvor det var gjort bruk av barn, lik, dyr, vold eller tvang.

Til tross for at utvalget fant at straffenivået for seksuelle overgrep mot barn var noe lavt, ble det ikke foreslått endringer i strafferammene fordi man kunne justere straffenivået innenfor gjeldende rammer. Også for voldtekt mente utvalget at straffenivået var noe lavt, men også her burde man kunne foreta de nødvendige justeringer innenfor de eksisterende strafferammer. ${ }^{32}$

Utredningen ble langt på vei lagt til grunn for departementets forslag til endring i straffelovens regler om seksuallovbrudd. Men departementet foreslo å kriminalisere grovt uaktsom voldtekt, samtidig som flere overgrep enn før skulle bli å anse som voldtekt. Blant annet skulle den som hadde seksuell omgang med en bevisstløs person straffes for voldtekt. Den seksuelle lavalder på 16 år ble foreslått opprettholdt, men departementet var enig i at det ikke burde 
foretas en generell kriminalisering av kjøp av seksuelle tjenester på nåværende tidspunkt. Spørsmålet skulle imidlertid revurderes etter to år. Kjøp av seksuelle tjenester av personer under 18 år ble imidlertid foreslått kriminalisert med en strafferamme på to år. ${ }^{33}$ Departementet gikk ikke inn for noen liberalisering av pornografibestemmelsen. Heller ikke departementet fant grunn til å endre strafferammene selv om straffenivået for grove voldtektssaker var lavt. Endringer burde finne sted gjennom rettspraksis. ${ }^{34}$

Et vekslende flertall i Justiskomiteen støttet i det vesentlige departementets forslag. Det ble understreket at straffenivået i sedelighetssaker var for lavt, og at komiteen forventet at domstolen fulgte opp de signaler som nå var fremkommet i lovgivningsarbeidet. Flertallet foreslo likevel i tillegg en hevning av minstestraffen for voldtekt fra 1 til 2 år, og tilsvarende hevning i forhold til seksuell omgang med barn under 14 år dersom den seksuelle omgang var samleie. ${ }^{35}$ Vedtaket ble sanksjonert som lov av 11. august $2000 \mathrm{nr}$. 76 .

\subsection{Straffelovkommisjonens delutredning VII - NOU 2002: 4 Ny straffelov}

Den 4. mars 2002 fremla Straffelovkommisjonen forslag til ny straffelov. Det er imidlertid ikke tale om en fullstendig ny straffelov: Det er fremlagt et revidert utkast til alminnelig del, og skisser til kapitlene i den spesielle del. ${ }^{36}$ Før øvrig inneholder utredningen drøftelser av en rekke generelle problemstillinger knyttet til kriminalisering og strafferammer mv. som vil ha sentral betydning for det videre arbeidet med den spesielle del. ${ }^{37}$

Bakgrunnen for at man fant behov for å foreta en ny gjennomgang av den alminnelige del, var at kommisjonens forutsetning i $1991 \mathrm{om}$ en delreform, ikke ble fulgt opp. Forslaget fra 1991 var utformet på en måte som skulle gjøre det mulig å foreta en trinnvis lovgivning. Når dette ikke ble gjennomført, var det behov for å fjerne de midlertidige overgangsbestemmelser og omarbeide utkastet med sikte på å presentere det $\mathrm{i}$ et endelig, og fullstendig utkast. ${ }^{38}$

Det gjenstår etter dette en del arbeid før det kan fremlegges et endelig utkast til en ny straffelov. Kommisjonen foreslo imidlertid at det ble nedsatt flere underutvalg for å behandle spørsmål som bl.a. endringer i særlovgivningen som følger av en ny straffelov, straffelovgivningen for sjøfartsforhold og til beskyttelse av rikets sikkerhet. Det siste forslaget var allerede fulgt opp da Straffelovkommisjonen avga sin innstilling i mars 2002.

Straffelovkommisjonen ble etter avleveringen av innstillingen nedlagt. Arbeidet med ny straffelov videreføres nå i departementet under ledelse av lovrådgiver dr. juris Tor-Geir Myhrer.

\subsection{Straffelovkommisjonens delutredning VIII - NOU 2003: 18 Rikets sikkerhet} Den 30. juni 2003 avga det siste underutvalget under Straffelovkommisjonen sin innstilling. Utvalget - senere omtalt som Lundutvalget fordi det var ledet av høyesterettsdommer Ketil Lund - var oppnevnt 21. desember 2001 for på bak- 
grunn av trusselbildet å gjennomgå reglene til vern mot statsforfatningen og deler av militær straffelov mv. ${ }^{39}$ I samsvar med den skissen som var fremlagt $\mathrm{i}$ NOU 2002: 4, har utvalget utarbeidet forslag til nye straffebestemmelser i den fremtidige straffelovs kapittel $17 .{ }^{40}$ Kapittelet har fătt følgende overskrift: «Vern av Norges selvstendighet og forfatning, freden og andre grunnleggende nasjonale interesser». I forhold til skissen som ble fremlagt i NOU 2002: 4, inkluderer kapittel 17 også flere av de bestemmelser som kommisjonen hadde forutsatt skulle inntas i kapittel 18. De øvrige bestemmelser som Straffelovkommisjonen forutsatte skulle inngå i kapittel 18, men som Lundutvalget ikke tok med i kapittel 17 , omhandler straffebud som verner valgordningen. ${ }^{41}$

\subsection{Oppsummering}

Reformarbeidet har pågått i 23 år, uten at det foreligger noe endelig utkast til lov. Det må imidlertid understrekes at man med den skissen som er fremlagt $\mathrm{i}$ 2002, har et godt utgangspunkt for det videre arbeid med den spesielle del. Dertil foreligger det nå et utkast til kapittel $17 \mathrm{i}$ den nye straffeloven, jfr. NOU 2003: 18. Deler av den øvrige straffeloven har blitt fortløpende revidert gjennom årene. Det er derfor ikke gitt at det gjenværende arbeidet vil være like ressurskrevende som arbeidet så langt har vist seg å være.

\section{Sentrale problemstillinger i utredningen om ny straffelov}

\subsection{Innledning}

Innenfor rammen av en artikkel, er det ikke mulig å ta opp alle spørsmål som utkastet til ny straffelov aktualiserer. Jeg har valgt ut enkelte tema som jeg mener kan ha en bredere interesse i skandinavisk sammenheng. Først vil jeg redegjøre for kommisjonens vurderinger knyttet til hva som bør kriminaliseres, jfr. neste punkt. Deretter behandles vurderingen av strafferammer og straffenivå, jfr. punkt 3.3. Hvilke handlinger som bør inntas i straffeloven tas opp i punkt 3.4. I punkt 3.5 tar jeg opp enkelte andre generelle endringer i så vel den materielle som prosessuelle strafferett. Punkt 3.6 er viet kommisjonens syn på enkelte spørsmål som nylig er vurdert av lovgiver.

\subsection{Hva bør kriminaliseres?}

\subsubsection{Noen utgangspunkt}

Av Straffelovkommisjonens mandat fremgikk det at kommisjonen burde vurdere hvilke handlinger det var grunn til å straffesanksjonere. Særlig skulle kommisjonen vurdere om det var hensiktsmessig å opprettholde alle straffebestemmelsene i spesiallovgivningen, og om noen av disse eventuelt burde overføres til straffeloven..$^{42}$ Det er grunn til å understreke at kommisjonen gjennom et tilleggsmandat fra 1994 og en senere presisering av dette i 1998, ikke har foretatt en fullstendig gjennomgang av spesiallovgivningen..$^{43}$ Kapittel 4 i utredningen inneholder imidlertid kommisjonens standpunkter mht. hvilke forhold som det 
bør legges vekt på ved avgjørelsen av om et forhold skal kriminaliseres. Kommisjonen har særlig pekt på prinsipper for å begrense bruken av straff. ${ }^{44}$

Kommisjonen tar utgangspunkt $\mathrm{i}$ individenes handlefrihet, og at inngrep $\mathrm{i}$ denne krever en særlig begrunnelse. Som den strengeste reaksjon for å begrense handlefriheten kan samfunnet anvende straff. Men samtidig fremhever kommisjonen at man også kan tenke seg andre reaksjoner enn straff for brudd på normer. Det er derfor ikke handlefrihetens grenser som har stått sentralt, men grensene for hva som skal være straffbart ${ }^{45}$ Forslagene i utkastet til ny straffelov har tatt utgangspunkt i bestemmelsene i den eksisterende straffelov, men samtidig har kommisjonen foretatt en selvstendig vurdering av hvilke handlinger det er nødvendig å belegge med straff. Bakgrunnen er at holdningene til hva som skal være straffbart endrer seg over tid, og at man derfor må ha en åpen innstilling til om det som ble kriminalisert i 1902 fortsatt fortjener å vernes gjennom trussel om straff i $2002 .{ }^{46}$

Kommisjonens utgangspunkt er selvsagt at ikke enhver handling som et flertall i folket misliker kan belegges med straff. Det er primært handlinger som medfører en fare eller skade som bør straffes, og kommisjonen omtaler dette som skadefølgeprinsippet. ${ }^{47}$

\title{
3.2.2. Skadefølgeprinsippet
}

Kommisjonens bruk av skadefølgeprinsippet:

\begin{abstract}
«... innebærer ... at straff bare bør brukes som reaksjon på handlinger som medfører, eller kan medføre, at noen påføres skade. Prinsippet bygger på at individet i størst mulig grad bør kunne handle fritt, og at straff bare bør kunne anvendes når tungtveiende grunner taler for det. Slike tungtveiende grunner vil stort sett bare foreligge når en handlingstype kan medføre skadevirkninger. I dette ligger at en type atferd ikke bør være straffbar bare fordi et flertall misliker den. ...» NOU 2002: 4 s. 79 andre spalte.
\end{abstract}

Som kommisjonen fremhever, er det første spørsmålet hva som skal anses som «skade» etter en slik definisjon. Det er ingen tvil om at drap og tyveri representerer en skade, men det kan oppstå tvil i forhold til andre handlinger. Og det er heller ikke vanskelig å påvise noen grunnleggende moraloppfatninger som bør avspeiles i straffeloven, for eksempel respekt for liv og eiendom. Men at en handling kan svekke den felles samfunnsmoral, vil i følge kommisjonen ikke bære langt ved avgjørelsen av hva som skal kriminaliseres. For det første kan det være vanskelig å identifisere en felles samfunnsmoral når man kommer utenfor de sentrale verdier, og for det andre kan det reises spørsmål om trussel om straff vil ha noen effekt mht. å endre samfunnsmoralen. På denne bakgrunn foreslår kommisjonen for eksempel at bigami ikke lenger bør være straffbart, se strl. $\S 220 .^{48}$

Er det usikkert om en handling kan medføre skade, må man i følge kommisjonen ta hensyn til hvor stor fare for skade som må kreves før handlingen 
kriminaliseres. Her kan det ikke gis noe generelt svar: Dersom de mulige skader er store, bør man kunne kriminalisere ved en lav sannsynlighetsgrad. Dessuten må man legge vekt på de hensyn som tilsier at den aktuelle handling bør være tillatt. Mange handlinger som skaper risiko, blir likevel tillatt fordi de har et fornuftig formål. Som eksempel nevner kommisjonen fritidsaktiviteter ${ }^{49}$ men også sportsaktiviteter faller inn under denne gruppen.

Skadefølgeprinsippet reiser også spørsmål om man bør begrense kriminaliseringen slik at skader som utelukkende rammer gjerningspersonen selv, bør falle utenfor området for det straffbare. Kommisjonen mener at slike handlinger langt på vei må aksepteres. Flertallet i kommisjonen foreslår derfor at man bør avkriminalisere egen bruk av narkotika. Kommisjonens flertall anfører at:

«En hovedbegrunnelse for å unngå paternalistiske straffebud er at det er mer adekvat å sette inn helsemessige tiltak av ulik art for å forhindre slike handlinger.» NOU 2002: 4 s. 81 første spalte.

Som kommisjonen selv anfører, vil imidlertid ikke alltid skade på gjerningspersonen selv bare ramme ham, men kan også ramme hans nærmeste eller samfunnet som sådan. Det er dette som ligger til grunn for at mindretallet går imot å avkriminalisere egen bruk av narkotika. ${ }^{50}$

Selv om en handling ikke har konkrete skadevirkninger, mener kommisjonen at det også kan være aktuelt å kriminalisere atferd som ledd i kontroll og ut fra effektivitetshensyn. Som eksempel vises det til straffebudet om etterfølgende alkoholnytelse, jfr. vtrl. § 22 andre ledd. Kommisjonen mener på denne bakgrunn:

«... at det unntaksvis kan være berettiget å kriminalisere atferd som ikke i seg selv har skadevirkninger. Lovgiver bør imidlertid være tilbakeholden med å kriminalisere slik atferd. Det bør vurderes meget nøye hvor stort inngrep en slik straffebestemmelse eventuelt vil gjøre i borgernes frihet, og om et slikt inngrep framstår som rimelig i forhold til hvor sterke interesser som knytter seg til kontroll med en type skadelig virksomhet.» NOU 2002: 4 s. 81 andre spalte.

\subsubsection{Straffens begrunnelse som begrensning i kriminaliseringen}

Kommisjonen fremhever at straffens begrunnelse, berettigelse og hensiktsmessighet også må trekkes inn ved vurderingen av hva som skal kriminaliseres. ${ }^{51}$ Både rettferdighetsbetraktninger og nyttevirkninger kan begrunne bruk av straff, for eksempel for å hindre skadelig atferd. Men:

«... For at straff skal være tilstrekkelig begrunnet, må de hensyn som taler for bruk av straff, veie tyngre enn de hensyn som taler mot. Etter kommisjonens syn er det klart at straffen som institusjon er tilstrekkelig begrunnet, i den forstand at det finnes mange tilfeller der hensynene for bruk av straff veier tyngre enn hensynene mot. Kommisjonens oppgave er imidlertid å vurdere hvilke konkrete handlingstyper som skal kriminaliseres. I denne sammenheng er det viktig å kartlegge også de hensynene som taler mot bruk av straff. ...» NOU 2002: 4 s. 82 første spalte. 
Ved bruk av straff kan man ikke ensidig fokusere på hva man kan oppnå, fordi dette ikke nødvendigvis bærer en tilstrekkelig moralsk legitimering av straffen - idømmelse av straff krever en moralsk berettigelse utover nyttevirkninger. ${ }^{52}$ Når bruk av straff er moralsk berettiget, er etter kommisjonens syn et vanskelig spørsmål:

«... For at samfunnet skal være berettiget til overhodet å bruke straff som virkemiddel, må det imidlertid også kreves at en straffereaksjon framstår som rimelig eller rettferdig. Humanitetshensyn og forholdsmessighetsbetraktninger står her sentralt. ...» NOU 2002: 4 s. 82 andre spalte.

Det avgjørende for kriminalisering bør være om straffen samlet sett er en hensiktsmessig reaksjon overfor den aktuelle handling. Man må da avveie nytten mot omkostningene. Dette er imidlertid usikre størrelser, noe som tilsier en grundig vurdering før man tyr til straff. ${ }^{53}$

Straffens prevensjonsvirkninger har tradisjonelt stått sentralt $i$ vurderingen av nytten. I denne sammenheng fremhever kommisjonen at lovgivers oppfatning av nytten ofte er bygget på et for optimistisk syn på hva man kan oppnå gjennom straff. Hensynene mot kriminalisering vil variere etter de konkrete forhold, men som begrensende faktorer fremhever kommisjonen bl.a. de menneskelige belastningene ved bruk av ubetinget fengselsstraff, samfunnets ressursbruk for å håndheve det aktuelle straffebud, ulempene forbundet med utbyggingen av et eventuelt «kontrollsamfunn», samt det generelle hensynet som taler mot å kriminalisere bagatellforgåelser fordi dette kan medføre at respekten for straffen svekkes. ${ }^{54}$

\subsubsection{Alternative sanksjoner?}

Før man kriminaliserer en handling bør det vurderes om andre sanksjoner enn straff kan være egnet til å gi et like godt vern om det aktuelle rettsgode. I så fall bør man velge en slik sanksjon fremfor straff..$^{55}$

For det første kan det være aktuelt å se på privatrettslige sanksjoner som kan ivareta det hensyn som en straffetrussel ellers ville ha gjort. Av denne grunn mener kommisjonen at straffen for ærekrenkelse kan begrenses til de mest graverende tilfeller, slik at vernet om æren for øvrig må håndheves gjennom erstatning, oppreisning og mortifikasjon..$^{56}$

For det andre kan overtredelser møtes med administrative sanksjoner. Med dette begrepet:

«... siktes det til reaksjoner som ilegges av forvaltningen som følge av et lovbrudd, som har et helt eller delvis pønalt, preventivt eller gjenopprettende formål, og som ikke formelt er straff etter strl $\S \S 15$ og 16.» NOU 2002: 4 s. 85 første spalte.

Under henvisning til Rt. 2000 s. 996 hvor $60 \%$ tilleggsskatt ble ansett som «a criminal charge»» etter EMK artikkel 6 (1), fremhevet kommisjonen at selv om 
en sanksjon anses å falle inn under artikkel 6 (1), er ikke dette til hinder for at den ilegges av forvaltningen. ${ }^{57}$ Det må imidlertid være adgang til en domstolsprøving i samsvar med konvensjonens $\mathrm{krav} .{ }^{58} \mathrm{Og}$ dersom en sanksjon faller utenfor virkeområdet til artikkel 6, er det etter kommisjonens mening likevel viktig å sørge for betryggende saksbehandlingsregler. Som eksempel på administrative sanksjoner nevner kommisjonen gebyr eller avgifter, tilbakekall av tillatelser, inndragning og vinningsavståelse, administrative advarsler og offentliggjøring av identiteten til lovbryteren. ${ }^{59}$

Kommisjonen legger til grunn at det innenfor flere områder i større grad vil være mulig å ta i bruk slike sanksjoner fremfor straff. ${ }^{60}$ Men siden det allerede 26. januar 2001 var nedsatt et eget utvalg - Sanksjonsutvalget - for å vurdere alternative sanksjoner til straff, fremmet ikke Straffelovkommisjonen noe konkret forslag til hvilke sanksjoner som kan tenkes å tas i bruk og på hvilke områder man kan bruke slike sanksjoner. ${ }^{61}$ Sanksjonsutvalget fremla sin innstilling 16. mai 2003, se NOU 2003: 15. Det er tale om en omfattende utredning som tar sikte på innføre et helhetlig system for administrative sanksjoner. Dette vil legge forholdene bedre til rette for å håndheve handlingsnormer uten at de gjøres straffbare. Dertil har man søkt å ivareta hensynet til den enkeltes rettssikkerhet. Jeg mener at forslaget bør gjennomføres, og det vil i så fall representere en omfattende omlegging i norsk sanksjonspraksis. Av plasshensyn er det imidlertid ikke rom for å gå nærmere inn på de konkrete forslag.

\subsubsection{Om kriminalisering av uaktsomme handlinger}

Mens Straffelovkommisjonen av 1980 la til grunn at man burde vurdere om det var behov for i større utstrekning å kriminalisere uaktsomme handlinger ${ }^{62}$ har kommisjonen av 1994 et annet syn på dette spørsmålet. Uaktsomme overtredelser er mindre straffverdige enn forsettlige overtredelser. Med utgangspunkt i grunnsynet om at man må være tilbakeholden med å bruke straff, mener kommisjonen at skyldkravet i strafferetten som hovedregel bør være forsett. For å ramme uaktsomhet må det kreves en særlig begrunnelse, og straff bør bare anvendes etter en grundig vurdering av behovet i forhold til den enkelte handlingsnorm. Fare for alvorlige skadefølger og effektivitetsbetraktninger i tilknytning til straffesanksjonerte plikter vil være viktige momenter i vurderingen. I sistnevnte tilfelle kan et krav om forsett medføre store bevisproblemer. Også i andre tilfeller hvor bevissituasjonen er vanskelig, kan det være behov for uaktsomhetsansvar for å ramme skjult forsett. ${ }^{63}$

Kommisjonen har på denne bakgrunn ikke funnet at behovet for å ramme skjult forsett er tilstrekkelig til å kriminalisere uaktsomt brudd på meldeplikten ved dødsfall, se skissen til $\S 19-7$ jfr. NOU 2002: 4 s. 294 andre spalte. Se på den andre siden skissen til § 19-1 for så vidt gjelder videreføring av strl. § 343 andre ledd om arbeidsgivers unnlatelse av å foreta lønnstrekk for krav under tvangsfullbyrdelse, hvor det er foreslått å kriminalisere uaktsom overtredelse begrunnet i effektivitetshensynet, se NOU 2002: 4 s. 296 første spalte. I for- 
hold til falsk alarm fant kommisjonen at effektivitetshensyn tilsa at det var tilstrekkelig at man i forhold til følgen av bruken av nødsignal mv., krevde grov uaktsomhet, se NOU 2002: 4 s. 300 ved omtalen av skissen til § 20-6. Tilsvarende er lagt til grunn ved skissen til $\S 21-8$ som skal erstatte strl. § 382 om utbredelse av utilbørlige voldsskildringer gjennom film eller video, jfr. NOU 2002: 4 s. 307 andre spalte.

Generelt sett mener kommisjonen at behovet for uaktsomhetsansvaret ikke virker tilstrekkelig gjennomtenkt, særlig innenfor spesiallovgivningen. For å sikre at man i fremtiden får en slik vurdering, foreslår kommisjonen at skyldkravet som hovedregel skal være forsett innenfor hele straffelovgivningen. ${ }^{64}$

Som følge av kommisjonens syn på kriminalisering av uaktsomhet, foreslår den videre at hovedregelen bør være at bare grov uaktsomhet kriminaliseres. Effektivitetshensyn vil bare $\mathrm{i}$ begrenset grad kunne begrunne å kriminalisere simpel uaktsomhet. De tilfellene hvor straffansvar for vanlig uaktsomhet kan forsvares, er særlig hvor feil eller uforsiktighet kan medføre alvorlige skadefølger.

Kommisjonen mener som nevnt at det innenfor visse områder hvor det er særlige bevisproblemer, kan være aktuelt med uaktsomhetsansvar for å ramme såkalt skjult forsett. Dette kan medføre at man kriminaliserer uaktsomhet ut fra effektivitets- og kontrollhensyn, uavhengig av om handlingen i seg selv anses som straffverdig. Kommisjonen fremhever imidlertid at utgangspunktet må være at uaktsomme overtredelser som ikke anses straffverdige, heller ikke kriminaliseres:

«... Dersom det i et slikt tilfelle ikke lar seg gjøre å føre bevis for forsett, kan man hevde at det nettopp er fordi det ikke med betryggende grad av sikkerhet lar seg fastslå at det er foretatt en straffverdig handling. Straff i et slikt tilfelle kan virke urimelig, og kriminalisering av uaktsomhet for å ramme «skjult forsett» vil fortone seg som en senking av det beviskravet som er satt til vern for borgerne på strafferettens område.» NOU 2002: 4 s. 88 andre spalte.

Om man i slike tilfeller likevel skal kriminalisere uaktsomme handlinger, vil bero på en avveining mellom det urimelige i å straffe en handling som ikke i seg selv anses som straffverdig, og hensynet til kontrollbehovet. I enkelte bestemmelser har kommisjonen funnet at det ut fra en slik avveining er behov for uaktsomhetsstraff. ${ }^{65}$ Som eksempel kan det vises til skissen til § 25-9 om etterfølgende alkoholnytelse hvor det kreves grov uaktsomhet. ${ }^{66}$

\subsubsection{Kriminalisering av forsøkshandlinger}

Forsøksstraff er særlig begrunnet i lovovertrederens subjektive forhold - man straffer den forbryterske vilje selv om den ikke har hatt noen følger. Men ved den strafferettslige bedømmelsen av en handling, er det ingen tvil om at eventuelle følger vil ha betydning. Kommisjonen fremhever at i de fleste tilfeller vil forsøket være mindre straffverdig enn den fullbyrdede handling. Med utgangspunkt $\mathrm{i}$ kommisjonens grunnsyn om at man skal begrense bruken av 
straff, legger den til grunn at det bare er forsøk på alvorlige lovbrudd som bør kriminaliseres. Som hovedregel foreslår den derfor å begrense kriminaliseringen til forsøk på handlinger med strafferamme over 6 måneder. ${ }^{67}$

I noen tilfeller er forsøk likestilt med fullbyrdet forbrytelse, se for eksempel strl. § 127 om vold mot offentlig tjenestemann:

«Den, som ved Vold søger at formaa en offentlig Tjenestemand til at foretage, eller undlade en Tjenestehandling eller at hindre ham under en saadan, ....

Da vil det ikke være rom for å oppnå straffrihet ved tilbaketreden, jfr. strl. § 50, og regelen om at forsøk straffes mildere enn den fullbyrdede forbrytelse vil heller ikke komme til anvendelse, se strl. § 51 første ledd. Straffelovkommisjonen fremhever at det i mange tilfeller kan virke urimelig at det ikke er adgang til straffri tilbaketreden. Den som trer tilbake viser ikke det samme forbryterske forsett, og dessuten kan en regel om straffrihet ved tilbaketreden motivere gjerningspersonen til ikke å gjennomføre handlingen ${ }^{68}$ Kommisjonen foreslår derfor at bl.a. bestemmelsen om vold mot offentlig tjenestemann - skissen til § 19-1, samt forulempelse av offentlige tjenestemann - skissen til § 19-2, utformes slik at det sondres mellom forsøk og fullbyrdet handling. ${ }^{69}$ Det samme gjelder for promillekjøring. ${ }^{70}$ Straffri tilbaketreden vil da være mulig.

Kommisjonen foreslår for øvrig ikke å videreføre regelen om at forsøk skal straffes mildere enn den fullbyrdede forbrytelse. I stedet foreslås det at man innfører en adgang til å straffe mildere. Dette innebærer at det ikke er samme behov for å likestille forsøk med fullbyrdet overtredelse. Forsøket kan straffes like strengt eller strengere enn den fullbyrdede handling. På denne bakgrunn foreslår kommisjonen at likestillingen av forsøk og fullbyrdet handling i mange tilfeller bør falle bort. Bare i tilfeller hvor dette er særlig begrunnet, foreslås det en slik likestilling, se for eksempel skissen til §§ 18-1 og 18-2 om høyforræderi. ${ }^{71}$

\subsubsection{Kriminalisering av forberedende handlinger}

Vi har ingen generell bestemmelse som rammer forberedelse av straffbare handlinger. Enkelte særlige forberedelseshandlinger er likevel kriminalisert, se som eksempel strl. § 161 som bl.a. rammer den som anskaffer sprengstoff i den hensikt å begå en forbrytelse. Et nytt eksempel på kriminalisering av forberedelseshandlinger har man i strl. $\S 147$ b som ble vedtatt ved lov av 28. juni 2002 nr. 54 i tilknytning til gjennomgangen av straffelovgivningen etter terroranslaget mot USA 11. september 2001. ${ }^{72}$ Bestemmelsens første ledd lyder:

«Med fengsel inntil 10 år straffes den som fremskaffer eller samler inn penger eller andre formuesgoder, med det forsett at formuesgodene helt eller delvis skal finansiere terrorhandlinger eller andre overtredelser av $\S 147$ a.»

Straffelovkommisjonen har flere ganger gitt uttrykk for at hovedregelen fortsatt 
bør være at man ikke kriminaliserer forberedelseshandlinger. Men det kan tenkes unntak for forberedelse av særlig alvorlige handlinger, men at dette i tilfelle må vurderes i tilknytning til utformingen av bestemmelsene i straffelovens spesielle del. ${ }^{73}$

I anledning arbeidet med straffansvar for forberedelseshandlinger innhentet Straffelovkommisjonen en betenkning av professor dr. juris Erling Johannes Husabø. ${ }^{74}$ Husabø fremhever at det bør stilles visse krav før man kriminaliserer forberedelseshandlinger. Problemstillingen er imidlertid ikke den samme som ved spørsmål om å kriminalisere handlinger mer generelt. Bakgrunnen er at forberedelseshandlingene er et aksessorium til den allerede kriminaliserte handlingen. Spørsmålet er derfor hvor lenge før den fullbyrdede forbrytelse man skal la straffansvaret inntre. Gjennom forsøkshandlinger har man allerede utvidet området for det straffbare. Kriminalisering av forberedelseshandlinger vil medføre en ytterligere utvidelse. Spørsmålet om kriminalisering av forberedelseshandlinger kunne derfor ikke vurderes løsrevet fra det aktuelle rettsgode som man tok sikte på å verne. ${ }^{75}$

Husabø fremhever at man må økonomisere straffansvaret. Jo flere handlinger som rammes av straffelovgivningen, jo mindre ressurser blir det totalt sett til å bekjempe den enkelte overtredelse. Eventuell kriminalisering av forberedelseshandlinger må også ivareta hensynene som ligger bak det strafferettslige legalitetsprinsipp, jfr. Grl. § 96 og EMK artikkel 7, siden det vil være større avstand mellom den kriminaliserte handling og den fullbyrdede forbrytelse. Dette kan medføre at det vil være vanskelig å oppfylle konkretiseringskravet. I alle tilfeller må kriminalisering av forberedelseshandlinger bygge på et konkret behov for å utvide straffansvaret. Utviklingen av den organiserte kriminalitet kan representere et slikt behov. Men forutsetningen må likevel være at straffansvaret vil ha en avskrekkende funksjon. Denne vil normalt være tilstrekkelig ivaretatt gjennom straffansvaret for fullbyrdet overtredelse av det aktuelle straffebud som forberedelseshandlingen knytter seg til. Og den som ikke lar seg avskrekke i forhold til å begå fullbyrdet overtredelse, vil neppe la seg avskrekke av et straffansvar for forberedelseshandlinger. ${ }^{76}$

Kriminalisering av forberedelseshandlinger har også en side mot straffeprosessuelle tvangsmidler, ved at man derigjennom utvider området for bruken av disse. Men en slik sideeffekt kan ikke i seg selv begrunne en utvidelse av straffansvaret. Behovet for å ta $\mathrm{i}$ bruk tvangsmidler må vurderes selvstendig og uavhengig av spørsmålet om man skal kriminalisere forberedelseshandlinger. Uten en slik vurdering kan en utvidelse av straffansvaret få en uønsket effekt mht. å utvide politiets adgang til inngrep i den private sfære. ${ }^{77}$

Utvidelse av straffansvaret kan også få andre uheldige virkninger. For det første vil enhver endring medføre en innskrenkning i den generelle handlefriheten. Vekten av dette argumentet vil imidlertid avhenge av de konkrete omstendigheter, noe som taler mot at man foretar en generell kriminalisering av forberedelseshand- 
linger. ${ }^{78}$ For det andre vil man få en forflytning av fokuset fra den ytre handlingen til gjerningspersonens forsett. Dette medfører at det avgjørende for om en i det ytre uskyldig handling er straffbar eller ikke, er gjerningspersonens forestillinger og motiv. Man går fra en «handlingsstrafferett» til en «sinnelagsstrafferett». Det vil ofte være vanskelig å avgjøre om en person har hatt det tilstrekkelige forsett, ${ }^{79}$ og en dreining av strafferetten i retning av gjerningspersonens forsett kan føre til øt risiko for uriktige domfellelser. ${ }^{80} \mathrm{I}$ det hele avviser Husabø at det er behov for en generell regel som rammer forberedelseshandlinger:

\footnotetext{
«Etter gjeldande rett er kriminaliseringa av avtalar og andre former for førebuing avgrensa til visse typar alvorlege brotsverk der eit forsøk eller ei fullføring lett kan føra til uboteleg skade. Lovgivar har dermed teke fatt i den typen tilfelle der førebuinga er særleg farleg og behovet for ei kriminalisering størst. Det er også i slike tilfelle folk si rettskjensle «krev», eller i alle fall legitimerer, eit utvida førebuingsansvar, ... Etter mitt syn er dette vegen å gå også i framtida. ...» NOU 2002: 4 s. 98 første spalte.
}

Straffelovkommisjonen sluttet seg til Husabøs syn, og straffansvar for forberedelseshandlinger er derfor vurdert i forhold til de enkelte bestemmelser hvor et slikt ansvar kan tenkes å ha betydning, se for eksempel skissen til strl. § 16-4 om avtale om krigsforbrytelser, § 20-9 avtale om kapring, § 27-7 avtaler om drap eller betydelig skade på legeme og helse mv. ${ }^{81}$ I tillegg har man foreslått å kriminalisere handlinger som ikke i seg selv er skadelige, men som kan medføre et skadelig resultat, jfr. skissen til § 23-7 om formidling av passord. Dertil er det foreslått et generelt kapittel - kapittel 21 - som tar sikte på å forebygge straffbare handlinger. Blant annet er forbudet mot å bære kniv eller våpen på offentlig sted, jfr. strl. § 352 a og vpl. § 27 b andre ledd jfr. § 33 første ledd andre punktum foreslått inntatt som $\S 21-1, \mathrm{og}$ ulovlig befatning med skytevåpen, ammunisjon og sprengstoff er foreslått inntatt som $\S 21-2 .{ }^{82}$

\subsubsection{Vurdering}

Det er ikke vanskelig å slutte seg til kommisjonens grunnleggende utgangspunkt om at man bør søke å begrense bruken av straff. ${ }^{83}$ Når det gjelder den nærmere gjennomføring av et slikt standpunkt, kan det imidlertid være rom for delte meninger. Det må imidlertid være riktig at man ikke kriminaliserer en handling bare fordi flertallet i folket misliker den ${ }^{84}$ Det er primært handlinger som medfører en skade som bør kriminaliseres.

Som kommisjonen selv understreker, kan det oppstå tvil om hva som skal anses å representere en skade. Og når det gjelder avkriminalisering av egen bruk av narkotika, er det dissens i kommisjonen. Jeg er enig med mindretallet som går imot en slik avkriminalisering. Flertallets hovedbegrunnelse om at de direkte skadevirkningene ved bruk av narkotiske stoffer bare rammer brukeren selv, ${ }^{85}$ finner jeg ikke overbevisende. Det er brukeren som rammes av de umiddelbare skadevirkningene, men et slikt perspektiv er for snevert. Nære pårørende ut- 
settes for store påkjenninger som følge av narkotikamisbruk, og en stor del av kriminaliteten i samfunnet har direkte eller indirekte tilknytning til narkotika. Jeg deler mindretallets standpunkt om at en avkriminalisering vil gi et uheldig signal. Og selv om det er mange andre tiltak som kan brukes for å begrense rekrutteringen til narkotikamiljøet, må det også være riktig å ta i bruk samfunnets strengeste virkemiddel for å hindre at unge personer făr ødelagt sitt liv.

Dermed er det ikke sagt at alt er såre vel med den norske narkotikapolitikken - heller tvert imot: Norge har visstnok flest sprøyteheroinister i Europa og flest overdosedødsfall per innbygger. ${ }^{86}$ Som flertallet fremhever, kan rent menneskelige hensyn tale for en avkriminalisering overfor langtkomne misbrukere. Slike personer sliter med store personlige og sosiale problemer. I forhold til denne gruppen kan det anføres at bruk av straff fremstår som urimelig og lite formålstjenlig. ${ }^{87}$ Jeg er enig i at samfunnet må gjøre mer for denne gruppen misbrukere, og overfor langtkomne misbrukere bør man søke å unngå å bruke straff. Det er flere alternative tiltak som her kan iverksettes. For eksempel kan en utbygging av metadonprosjektet medføre at denne gruppen får en bedre hverdag samtidig som de slipper å utsettes for trussel om straff. Det er derfor fullt mulig å beholde straffebudet som rammer egen bruk av narkotika, samtidig som man kan arbeide for en vesentlig forbedring av levevilkårene til langtkomne misbrukere. Personlig tror jeg ikke at flertallets standpunkt blir realisert. Forslaget ble av den sittende justisminister - Odd Einar Dørum (V) avlivet allerede ved overleveringen av innstillingen.

For øvrig kan det reises spørsmål om hvor langt straffeloven nødvendigvis bør søkes å holdes verdinøytral. Visse verdier er selvsagt nedfelt i loven, for eksempel respekten for liv og eiendom. Men for eksempel foreslås straffebestemmelsen mot bigami opphevet. Det er nok neppe særlig stort behov for en slik bestemmelse, men den er et symbol på de tradisjonelle verdier som det norske samfunnet er bygget på. Det er ikke gitt at den nye straffelov bør være helt uten slike kulturverdimarkører.

Et annet sentralt verdispørsmål er om det skal åpnes for aktiv dødshjelp. ${ }^{88}$ Flertallet i kommisjonen går imot at drap foretatt med den dreptes samtykke skal kunne medføre straffritak, mens mindretallet mener at dagens bestemmelse om straffnedsettelse i strl. $\S 235$ bør suppleres med en straffritaksregel. ${ }^{89}$ På dette punkt deler jeg flertallets oppfatning. Om nødrett kan få anvendelse i slike tilfeller har vært omdiskutert. I Rt. 2000 s. 646 la imidlertid Høyesterett til grunn at strl. $\S 47$ om nødrett ikke var anvendelig i en slik situasjon fordi lovgiver gjennom bestemmelsen i strl. $\S 235$ måtte anses å ha tatt stilling til spørsmålet - drap etter samtykke kan bare medføre straffnedsettelse. Jeg er derfor noe overrasket over at kommisjonen likevel legger tíl grunn at det kan tenkes situasjoner hvor nødrettsbestemmelsen kan få anvendelse. ${ }^{90}$ Dette er i realiteten et forsøk på å snikinnføre aktiv dødshjelp. Grunnen til at jeg er overrasket er ikke standpunktet i seg selv, men at det ikke foretas en tilstrekkelig anvisning av 
hvilke verdier som skal inngå i nødrettsvurderingen, og følgelig heller ikke hvilken vekt slike verdier skal ha i forhold til hverandre. I det hele er det uforståelig at ikke kommisjonen har vist til det mest utførlige arbeidet på dette området i Norge, nemlig Erling Johannes Husabøs avhandling: Rett til sjølvvalt livsavslutning? fra 1994. Kommisjonen har derimot flere henvisninger til forfattere som har et positivt syn på aktiv dødshjelp og nødrett. ${ }^{91}$ Husabø drøfter spørsmålet inngående på s. 242 flg., og konkluderer med at det ikke er rom for å bruke strl. § $47 \mathrm{i}$ en slik situasjon.

Også ved spørsmålet om aktiv dødshjelp kan det være rom for ulike syn. Men det er uansett uheldig å åpne for bruk av nødrett før man har gjennomdrøftet alle de vanskelige spørsmål en slik endring vil medføre. Kommisjonens drøftelse av spørsmålet er åpenbart utilstrekkelig i så måte. Den er dertil ubalansert når man utelater å trekke inn en forfatter som har gitt uttrykk for motsatte standpunkter sammenlignet med de forfattere som kommisjonen henviser til. En lovkommisjon er en premissleverandør til lovgiver. I så måte bør den ha en særlig objektivitetsplikt. På dette punktet mener jeg at kommisjonen ikke har oppfylt sin oppgave i så hensende.

Selv om jeg tidligere har hatt et åpent forhold til spørsmålet om aktiv dødshjelp, er jeg ikke i tvil etter å ha lest Husabøs fremstilling. Aktiv dødshjelp vil medføre en radikal endring av de grunnverdier som en rettsstat bør bekjenne seg til. ${ }^{92}$

For øvrig deler jeg kommisjonens syn på at man bør vurdere andre sanksjoner enn straff før man kriminaliserer en handling. Det samme gjelder kommisjonens syn på kriminalisering av forsøkshandlinger og forberedelseshandlinger. Også forslaget om å oppheve regelen om at forsøk skal straffes mildere enn en fullbyrdet forbrytelse er det grunn til å hilse velkommen. Jeg er imidlertid i tvil om man bør gå så langt $\mathrm{i}$ å avkriminalisere uaktsomhet. ${ }^{93}$ Rett nok er det sikkert mange straffebud i spesiallovgivningen som rammer uaktsomme overtredelser som er unødvendige og derfor kan oppheves. Men kommisjonens begrunnelse for ikke å kriminalisere uaktsomhet er lite treffende. At man søker å ramme skjult forsett eller å kriminalisere uaktsomhet i seg selv, medfører ingen senking av beviskravet. Når uaktsomhet er kriminalisert, innebærer dette at det stilles strengere krav til opptreden på det aktuelle området enn det som er tilfelle om man bare rammer forsettlige handlinger. ${ }^{94}$ Begrenser man seg til bare å kriminalisere forsettlige handlinger, kan man imidlertid risikere at beviskravet for at det er utvist forsett blir lempet i tilfeller hvor handlingen fremstår som straffverdig uten at man med den tilstrekkelig sikkerhet kan legge til grunn at tiltalte handlet forsettlig. ${ }^{95}$

I tillegg til den allerede nevnte strl. $\S 147$ b som er vedtatt etter at kommisjonen avga sin innstilling, er det vedtatt enda en bestemmelse som rammer forberedelseshandlinger. Ved lov av 4. juli 2003 nr. 78 fikk straffeloven en ny bestemmelse, strl. § $162 \mathrm{c}$, som lyder: 


\begin{abstract}
«Den som inngår forbund med noen om å begå en handling som kan straffes med fengsel $\mathrm{i}$ minst 3 år, og som skal begås som ledd i virksomheten til en organisert kriminell gruppe, straffes med fengsel inntil 3 år, med mindre forholdet går inn under en strengere straffebestemmelse. Forhøyelse av maksimumsstraffen ved gjentakelse eller sammenstøt av forbrytelser kommer ikke i betraktning.

Med organisert kriminell gruppe menes en organisert gruppe på tre eller flere personer som har som et hovedformål å begå en handling som kan straffes med fengsel i minst 3 år, eller hvor en vesentlig del av virksomheten består i å begå slike handlinger.»
\end{abstract}

Bakgrunnen for endringen er å gjennomføre artikkel 5 i FN konvensjonen om grenseoverskridende organisert kriminalitet fra 15 . november $2000 .{ }^{96}$ Med den generelle utformingen bestemmelsen har fått, kan det reises spørsmål om man nå $\mathrm{i}$ realiteten har fraveket utgangspunktet om at man i norsk rett ikke har en generell bestemmelse som rammer forberedelseshandlinger.

\title{
3.3. Strafferammer og straffenivå
}

\subsubsection{Innledning}

En sentral side av Straffelovkommisjonens mandat var:

«... å vurdere hvor strengt de enkelte lovbruddstyper skal behandles. I denne forbindelse må de ulike lovbruddtyper veies mot hverandre, og hensynet til rettferd stå sentralt.» NOU 1983: 57 s. 29 andre spalte.

I tilleggsmandatet fra 1994 er dette punktet fremhevet som en særlig viktig målsetning. ${ }^{97}$ Kommisjonen ba daværende stud. jur. Runar Torgersen om å utrede enkelte spørsmål i tilknytning til fastsettelse av strafferammer. ${ }^{98} \mathrm{Kom}$ misjonen tiltrådte i hovedsak denne utredningen. ${ }^{99}$

\subsubsection{Lovgivers innflytelse på straffenivået}

Kommisjonen tar først opp forholdet mellom lovgiver og domstoler ved fastsettelse av straffen. Selv om lovgiver trekker opp de generelle strafferammer i forhold til de enkelte lovbrudd, har man i Norge i stor grad overlatt til domstolene å utmåle en passende straff. I rettspraksis er det gjerne etablert et straffenivå som ligger langt lavere enn den øvre strafferamme. ${ }^{100}$

For noen overtredelser har det fra tid til annen vært press for å få høynet det generelle straffenivået. Dette har dels medført at det er innført minstestraffer, og dels at man på andre måter har søkt å gi politiske signaler til domstolen om å heve nivået. Kommisjonen mener at en hevning av øvre strafferamme aldri bør brukes i denne sammenheng, fordi dette kan medføre inflasjon i strafferammen uten at denne avspeiler den riktige bedømmelse av handlingens straffverdighet. ${ }^{101}$

Utenom endringer i strafferammen, kan lovgiver gjennom generelle straffutmålingsbestemmelser påvirke straffenivået. Vi har liten tradisjon for dette i vår lovgivning. Et unntak finner man i strl. § 59 andre ledd som ble tilføyd ved lov 
av 2. mars $2001 \mathrm{nr}$. 7, hvoretter man skal legge vekt på om domfelte har gitt en uforbeholden tilståelse. Dessuten ble vegtrafikkloven av 18. juni 1965 nr. 4 § 31 endret ved lov av 8. juli $1988 \mathrm{nr}$. 70, hvoretter man fikk utførlige retningslinjer om straffutmåling ved promillekjøring. ${ }^{102}$ Så vel Straffelovkommisjonen fra 1994 som kommisjonen av 1980 stiller seg kritisk til å gi generelle bestemmelser om straffutmålingen. ${ }^{103}$ Unntak finner man for så vidt gjelder utkastet til § 6-3-om at den ubetingede fengselsstraff for personer under 18 år på gjerningstidspunktet ikke kan overstige 8 år - og § 14-2 som viderefører strl. § 59 andre ledd om betydningen av at domfelte har avgitt en tilståelse. ${ }^{104} \mathrm{I}$ det hele er:

\begin{abstract}
«Kommisjonen ... generelt skeptisk til at lovgiver skal styre straffutmålingen for å sikre tilstrekkelig strenge straffer på bestemte områder, uavhengig av hvordan dette gjøres lovteknisk. Det er vanskelig å overskue konsekvensene av generelt formet lovgivning, og det kan dukke opp tilfeller som lovgiver ikke har forutsett, slik at den straffen loven gir anvisning på - gjennom minstestraff eller på annen måte - blir for streng. Dette kan lede til urimelige enkeltresultat eller juridisk tvilsomme avgjørelser, ... Dette innebærer at straffenivået for de ulike lovbruddstypene bør utvikles av domstolene gjennom konkrete saker, i nær kontakt med den virkeligheten som skal reguleres, og ikke låses av minstestraffer eller på annen måte overstyres.» NOU 2002: 4 s. 144 andre spalte.
\end{abstract}

Kommisjonen erkjenner at et slik synspunkt kan medføre at man ikke imøtekommer hensynet til å trekke inn den allmenne rettsfølelsen ved straffutmålingen, men finner at lekmannselementet i strafferettspleien ivaretar dette hensynet. For øvrig understreker kommisjonen at også maksimumsstraffer legger begrensninger på domstolenes straffutmålingspraksis. Men ut fra de rettssikkerhetshensyn som ligger til grunn for vår straffutmålingstradisjon, er en slik begrensning naturlig. ${ }^{105}$

\title{
3.3.3. Fastsettelse av strafferammene
}

Dagens straffelov opererer med 16 ulike fengselsstrafferammer - i måneder: 2 , $3,4,5$ og 6 - i år: $1,2,3,4,5,6,8,10,12,15$ og 21. Dette er de rammer som fremgår av de konkrete straffebud, men dersom man tar hensyn til kombinasjonen av andre regler som konkurrens mv., făr man enda flere strafferammer. ${ }^{106} \mathrm{En}$ slik gradering gir etter kommisjonens mening en urealistisk fingradering, og den nye straffelov bør inneholde færre nivå. Dette vil dessuten gjøre at strafferammesystemet blir mer oversiktlig. Kommisjonen foreslår derfor at man begrenser seg til 8 nivå - fengsel i 6 måneder eller 1 år - omtalt som strafferamme $\mathrm{i}$ «det lavere sjikt», dessuten fengsel i inntil 2, 3, 6, 10, 15 og 21 år. Den generelle nedre strafferamme på 14 dager foreslås videreført, men kommisjonen ønsker ikke å videreføre den øvre generelle strafferamme på 15 år. Lengstestraffen for det enkelte lovbrudd bør i stedet tas inn i den enkelte bestemmelse. ${ }^{107}$

Strafferammen i «det lavere sjikt» tar sikte på bot eller fengsel inntil 1 år. Dette vil få betydning for når forsøk kan straffes, jfr. at kommisjonen foreslår at sondringen mellom forbrytelser og forseelser oppheves, og kan også få proses- 
suell betydning mht. bruk av tvangsmidler etc. Siden kommisjonen ikke utarbeider forslag til konkrete straffebud, har man ikke hatt foranledning til å presisere når den vil foreslå strafferamme i dette sjiktet. Men i forhold til promillekjøring - skissen til § 25-8, etterfølgende alkoholnytelse - skissen til $\S 25-9$, brudd på taushetsplikt - skissen til § 23-1 og for mindre graverende skadeverk - skissen til § 23-11 og §29-1, foreslås det en strafferamme på 1 år. ${ }^{108}$

For øvrig foreslår kommisjonen at alle bestemmelser om «sidestrafferamme» ved gjentakelse oppheves. I gjeldende straffelov er det noe tilfeldig hvilke handlinger som har «sidestrafferamme», og kommisjonen ser ikke behov for en slik generell bestemmelse som man har i Sverige, jfr. BrB 26 kap. 3 §. Det er likevel grunn til å understreke at kommisjonen fortsatt anser gjentakelse som et relevant moment ved straffutmålingen innenfor straffebudets generelle strafferamme. I de tilfeller hvor dette kan ha praktisk betydning har man tatt høyde for dette ved fastsettelsen av rammen. ${ }^{109}$

\subsubsection{Differensiering av strafferammene}

Flere teknikker kan tas i bruk for å differensiere strafferammene etter handlingens grovhet. Straffeloven av 1902 har dels ulike strafferammer innenfor samme forbrytelse avhengig av om det foreligger spesielle omstendigheter, jfr. for eksempel strl. § 229 om legemsbeskadigelse, dels er grovheten differensiert gjennom likeartede bestemmelser, se for eksempel strl. § $257-3$ år for simpel tyveri, $\S 258-6$ år ved grovt tyveri og $§ 391$ a -6 måneder for naskeri. I skissen til spesiell del har man i større grad søkt å inndele handlinger som er like i art, men forskjellige i grovhet, i atskilte bestemmelser med egne strafferammer. Men en slik inndeling passer ikke for alle straffebud. For det første har man noen bestemmelser som aldri er kvalifisert straffverdige. I slike tilfeller er det ikke rom for å operere med grov overtredelse. Dessuten har man handlinger hvor det kan være vanskelig å angi momenter for vurderingen av om handlingen må anses som grov. Som eksempel nevner kommisjonen bestemmelsen om kapring, skissen til $\S 20-8 .{ }^{110}$ Dessuten vil det ved handlinger hvor man har begrenset erfaringsmateriale være vanskelig å foreta en gradering av strafferammen. For slike tilfeller finner kommisjonen det forsvarlig å gi en vid strafferamme. ${ }^{111}$

Som en konsekvens av de foreslåtte strafferammer, foreslås det ikke å videreføre dagens regulering hvor man ved «særdeles skjerpende» eller «særdeles formildende» omstendigheter får en egen sidestrafferamme. Også prosessuelt reiser slike bestemmelser særlige spørsmål: Det vil være en del av straffespørsmålet å avgjøre om slike omstendigheter foreligger, mens det for øvrig hører til skyldspørsmålet å avgjøre om handlingen må anses som grov. ${ }^{112}$ Dessuten foreslår kommisjonen at alle sidestrafferammer som følge av uforsettlige følgeskader, oppheves. ${ }^{113}$

Når man opererer med en inndeling av straffebudene etter handlingens grovhet, vil det bero på en konkret helhetsvurdering om handlingen faller inn 
under den ene eller andre kategori. Lovteksten skal inneholde viktige momenter i denne vurderingen, men selv om ett eller flere av disse er oppfylt, vil ikke handlingen uten videre bli ansett som grov. Motsatt kan en handling bli ansett som grov selv om den ikke inneholder momenter som er opplistet i loven. Tilsvarende lovgivningsteknikk vil bli brukt for å avgjøre om en overtredelse må anses som liten. For øvrig mener kommisjonen at man bare bør innta typiske momenter som har betydning for vurderingen, mens spesielle momenter som kan trekke i den ene eller andre retning, ikke bør med i loven. Dette innebærer at momenter som i dag er inntatt i enkelte straffebud kan bli utelatt $i$ den nye straffeloven, uten at man av den grunn anser den aktuelle omstendighet som irrelevant, se for eksempel strl. § 192 andre ledd litra b som nevner at gjerningspersonen har fremkalt at voldtektsofferet var bevisstløs eller var ute av stand til å motsette seg handlingen. Selv om dette momentet ikke foreslås videreført $\mathrm{i}$ skissen til § 28-2 om grov voldtekt, skal det likevel ha betydning for grovhetsvurderingen. ${ }^{114}$

For øvrig kan så vel objektive som subjektive momenter ha betydning for grovhetsvurderingen. Skadefølger vil, under forutsetning av at disse kan tilregnes gjerningspersonen som forsettlige eller uaktsomme, ha betydning. Forhold ved offeret bør også ha betydning, for eksempel om handlingen er begått overfor en forsvarsløs eller utsatt person. Videre bør man legge vekt på skyld og motiv. Derimot bør man ikke trekke inn forhold som er typiske for den aktuelle handling, for eksempel ved voldtekt hvor det er straffskjerpende at den seksuelle omgang var samleie, se strl. § 192 andre ledd litra a. Slike forhold bør avspeiles ved fastsettelsen av den generelle strafferammen. ${ }^{115}$

For tre bestemmelser foreslår kommisjonen et avvik fra at handlingens grovhet bestemmes ut fra en helhetsvurdering. For at det skal være tale om grov narkotikaforbrytelse, må to kumulative vilkår være oppfylt, jfr. skissen til § 25-2 hvor det kreves at det er tale om et betydelig kvantum og et særlig farlig stoff. Ved grov legemsskade, skissen til § $27-4$, vil det i utgangspunktet være tale om en skjønnsmessig helhetsvurdering, men slik at forsettlig tilføyelse av betydelig legemsskade medfører en høyere strafferamme uten rom for vurdering. Endelig foreslås det en egen strafferamme for det tilfellet at et grovt ran har hatt til følge døden eller betydelig skade på legeme, jfr. skissen til § 30-8. ${ }^{116}$

\subsubsection{Om minstestraffer}

Kommisjonen foreslår som nevnt ingen endring av den generelle minstestraff på 14 dager. Men straffeloven har i alt 37 bestemmelser med særlig minstestraff som spenner fra 2 måneder - strl. § 136 andre ledd om oppløp, til 21 år - strl. $\S 100$ om drap på regenten. Man har hatt delte erfaringer med minstestraffer. Slike kan medføre at domstolene blir tvunget til å avsi dommer som oppleves som urimelig strenge, noe som igjen kan medføre uriktige frifinnelser eller at man domfeller for et mindre forhold enn det som er funnet bevist. 
Straffelovkommisjonen foreslår derfor at de fleste minstestraffer avskaffes. ${ }^{117}$ For tre overtredelser foreslår imidlertid kommisjonens flertall å videreføre minstestraffer: Ved vanlig og grovt drap, jfr. skissene til $\S \S 27-5$ og 27-6, foreslås gjeldende minstestraff på 6 år videreført. ${ }^{118}$ For grov seksuell omgang med barn under 14 år foreslås også gjeldende minstestraff på 2 år opprettholdt, jfr. skissen til $\S 28-6 .{ }^{119}$ For disse overtredelsene mener flertallet at minstestraff er en nødvendig verdimarkering. Ett medlem foreslår dessuten at man for grov brannstiftelse - skissen til $\S 29-5$ - bør ha en minstestraff på 2 år. ${ }^{120}$

Mindretallet vil ikke videreføre noen bestemmelser om minstestraff. Selv om mindretallet er enig $\mathrm{i}$ at de handlinger som flertallet foreslår minstestraff for er noen av de mest graverende, har argumentene mot minstestraff også gyldighet $\mathrm{i}$ forhold til disse. Man bør ha tillit til at domstolene vil idømme tilstrekkelig streng straff, uten at loven skal tvinge frem et slikt resultat. Det er vanskelig å forutse alle relevante omstendigheter som kan ha betydning ved straffutmålingen, og en minstestraff vil avskjære domstolene fra å ta slike i betraktning. Dessuten anfører mindretallet at minstestraffer vil bryte med lovens strafferammesystem. ${ }^{121}$

\subsubsection{Relevante hensyn ved fastsettelsen av strafferammene}

Straffelovkommisjonen skulle som nevnt vurdere hvor strengt de ulike lovbrudd skulle straffes. Hensynet til rettferdighet skulle stå sentralt i denne vurderingen. Fastsettelse av strafferammer har vært, og burde fortsatt være, en så kompleks prosess at det ikke ville være mulig å gi entydige begrunnelser for strafferammene i de enkelte bestemmelser. I tilknytning til hvert kapittel i skissen til spesiell del, er det gitt en kort redegjørelse for de strafferammer man har valgt innenfor de ulike grupper straffebud. Men i tillegg redegjør kommisjonen også for de retningslinjer og prinsipielle vurderinger som er lagt til grunn i arbeidet med å fastsette strafferammene.

Kommisjonen tar utgangspunkt i begrepet «straffverdighet». Dette begrepet er:

«... et mål for hvor streng straffetrussel som bør oppstilles i de ulike straffebudene. I seg selv er begrepet «straffverdighet» lite opplysende. Det mås gis mening ved en redegjørelse for hvilke hensyn som skal ha betydning for straffverdighetsvurderingen. ... [I]kke ethvert hensyn ... kan begrunne en bestemt straff for en handling, [gir] naturlig ... grunnlag for å karakterisere handlingen som mer eller mindre straffverdig, ... Særlig gjelder dette rene kontrollhensyn og prosessuelle hensyn. Kommisjonen ... velger likevel av framstillingstekniske grunner å benytte straffverdighet som hjelpebegrep for hvor streng straffetrussel som bør gis i et straffebud, uavhengig av hvilke hensyn som virker inn på valget av strafferammen.» NOU 2002: 4 s. 152 første spalte.

Kommisjonen trekker deretter inn sentrale elementer i den svenske debatten om strafferammer når den fremhever at straffverdighetsvurderinger kan ses fra to sider: 
«... For det andre med sikte på forholdsmessighet mellom straffen for ulike lovbruddstyper. ... [S]ondringen mellom proporsjonalitet og ekvivalens er nærmere behandlet ... foran. Kommisjonen mener begge synsvinkler bør anvendes ved fastsettelsen av strafferammer. I de ulike rettferdighetsvurderingene som derved skal foretas, bør det legges vekt på en lang rekke hensyn. Rettferdighetshensyn bør stå sentralt, men også prevensjonshensyn og andre hensyn bør ha betydning. Dagens strafferammer og domstolenes straffutmålingspraksis for de ulike straffebestemmelsene danner et naturlig utgangspunkt for straffverdighetsvurderingene. ...» NOU 2002: 4 s. 152 første spalte.

Bakgrunnen for å trekke inn dagens strafferammer og etablert straffutmålingspraksis, er at domstolene gjennom daglig kontakt med konkrete saker har en bred innsikt mht. hvilke hensyn som gjør seg gjeldende ved straffutmålingen. Kommisjonen fant at det ut fra etablert praksis sammenholdt med det aktuelle straffutmålingsnivået, var grunnlag for å senke strafferammen for en del overtredelser. Strafferammen vil dermed fremstå som en mer realistisk begrensning for domstolene enn det tilfellet er i dag. Men det var ikke meningen å foreta en fullstendig tilpassing av strafferammene i forhold til etablert praksis. Ut fra en helhetlig vurdering av strafferammene kunne ikke kommisjonen nøye seg med å se hen til hva som var lagt til grunn i rettspraksis. Dertil var det ofte vanskelig å identifisere generelle straffverdighetsvurderinger som kunne ligge til grunn for fastsettelsen av strafferammer: Straffutmålingen for normalovertredelser ga lite grunnlag for å fastsette maksimumsstraffen. ${ }^{122}$

Heller ikke straffutmålingen ved de mest alvorlige overtredelser ville nødvendigvis gi særlig veiledning for fastsettelsen av maksimumsstraffen. For det første måtte maksimumsstraffen ta høyde for at det kunne forekomme grovere handlinger enn de som allerede var pådømt. Dertil kunne de groveste tilfeller være svært sjeldne, og således ville det være vanskelig å si noe om straffverdighetsvurderingen. Kommisjonen la derfor til grunn at etablert praksis ikke kunne representere noe sikkert eller presist utgangspunkt ved fastsettelsen av strafferammen. ${ }^{123}$

Kommisjonen fant oppgaven med å foreta en avveining av strafferammene ved ulike straffebud mot hverandre vanskelig, da det ikke var lett å veie ulike interesser eller lovbruddstyper opp mot hverandre. Innenfor likeartede overtredelser kunne man riktignok på logisk grunnlag komme frem til at for eksempel fullstendig ødeleggelse av en gjenstand er verre enn å påføre den en mindre skade, grov overtredelse er verre enn en mindre etc. Men kommisjonen fremhevet at det kunne være vanskelig å si noe om hvor mye mer straffverdig den grovere handling var. ${ }^{124}$ Ved sammenlikning av straffebud som verner ulike interesser, ville man ikke komme utenom at vurderingen vil ha preg av skjønn. ${ }^{125}$

På generelt grunnlag fremhevet imidlertid kommisjonen at graden av utvist skyld måtte tillegges stor betydning. Derfor måtte som hovedregel strafferammen for forsettlig overtredelse være strengere enn for uaktsom overtredelse. For strafferammer i det nedre sjikt kunne man av lovtekniske grunner imidlertid 
tenke seg å operere med en felles strafferamme. Det ble imidlertid forutsatt at domstolene, som i dag, skulle ta hensyn til skyldgraden ved straffutmålingen innenfor en felles strafferamme. ${ }^{126}$

Det er ikke uvanlig at strafferammene bestemmes ut fra lovtekniske hensyn, for eksempel for å oppnå en prosessuell virkning. Det som her fremstår som særlig aktuelt, er adgangen til å foreta pågripelse, jfr. strpl. § 171 hvor det kreves at handlingen etter loven må medføre høyere straff enn fengsel i 6 måneder. Kommisjonen fant at slike hensyn i utgangspunktet ikke kunne tillegges vekt. Kommisjonen fremhevet at man i stedet for tilpassing av strafferammene måtte foreta den nødvendige tilpassingen i prosesslovgivningen slik at det for eksempel skal være adgang til å pågripe for visse straffbare handlinger selv om strafferammen for forholdet ikke oppfyller det generelle kravet etter strpl. § $171 .{ }^{127}$ For strafferammer i det nedre sjikt, burde det likevel være rom for å legge vekt på lovtekniske forhold, for eksempel ut fra om det var behov for å kriminalisere forsøk, samt om det var behov for å kunne foreta pågripelse og varetektsfengsling. ${ }^{128}$

Kommisjonen fastsatte på denne bakgrunn følgende retningslinjer for valg av strafferammer:

Strafferammer i det lavere sjikt: det er nødvendig å reagere med straff, men straffverdigheten er lav. Det kan være tale om bagatellkrenkelser av vitale interesser, eller kvalifiserte krenkelser av interesser hvor det ikke er behov for et sterkt strafferettslig vern. Også hvor straffen er begrunnet ut fra kontrollhensyn, bør strafferammen være i det lavere sjikt. ${ }^{129}$

Strafferamme mellom 2 og 3 år: Denne strafferammen bør brukes når det er særlig viktig at den skal være en realistisk skranke for domstolene. Ved vinningsforbrytelser hvor det sondres mellom vanlig og grov overtredelse, vil det for den vanlige ligge til rette for å ha en strafferamme i dette sjiktet. Konkret foreslår kommisjonen at det bør være tilstrekkelig med 2 år, mens det for grove overtredelser bør være en strafferamme på 6 år. Ved vinningslovbrudd bør for øvrig private og offentlige interesser ha krav på samme vern. ${ }^{130}$

I dagens samfunn fremstår vern om liv og legeme som viktigere enn vern om økonomiske verdier. Strafferamme på 10 år eller mer, bør derfor bare brukes $\mathrm{i}$ forhold til bestemmelser som på en eller annen måte verner liv og legeme. I tillegg bør strafferammer i dette sjiktet også brukes ved straffebud som verner selve statsdannelsen. For alvorlige krenkelser av slike verdier bør det kunne anvendes 15 års strafferamme. ${ }^{131}$

Strafferammen på 21 års fengsel representerer det ytterste forsvar mot angrep på vitale interesser. Denne rammen vil i tillegg til vern om liv og statsdannelsen, også kunne være aktuell ved interesser som ligger nær opp til disse, for eksempel kapring, etc. ${ }^{132}$

Straffebud som rammer uaktsomme overtredelser, vil som regel kunne ha strafferamme i det nedre sjikt. Dersom det skal fastsettes en strengere straffe- 
ramme enn 2 år, bør dette kreve en særlig begrunnelse. Kommisjonen begrenser seg derfor til å foreslå strengere strafferamme kun ved fire overtredelser: uaktsom brannstiftelse og annen særlig farlig ødeleggelse, grov uaktsom betydelig skade på legeme og helse, samt grov uaktsom påføring av smitte eller fare for smitte. For alle disse overtredelser foreslås det en strafferamme på 3 år. For grovt uaktsomt drap foreslås det en strafferamme på 6 års fengsel. ${ }^{133}$

\subsubsection{Vurdering}

Det er ingen tvil om at det er påkrevd med en opprydding i lovens strafferammer. Den fingradering man finner i dagens lovgivning er - som kommisjonen fremhever - urealistisk. Jeg tror heller ikke det er noe å tape på å forlate sidestrafferammene ved gjentakelse. Som det understrekes av Straffelovkommisjonen, er dette noe det kan tas hensyn til innenfor den ordinære strafferammen. Det er imidlertid grunn til å merke seg at lovgiver ved lov av 4. juli 2003 nr. 78 endret strl. $\S 61$ om gjentakelsesstraff. Når den domfelte tidligere er domfelt for en handling av samme art, forhøyes strafferammen i straffebudet etter denne lovendringen til det dobbelte. Formålet med endringen er primært å skjerpe straffen for gjentatte vinnings-, volds- og seksualforbrytelser. ${ }^{134}$ Det er likevel ikke slik at den domfelte skal idømmes dobbel straff $i$ forhold til det etablerte straffenivået. De alminnelige straffutmålingsprinsipper skal fortsatt legges til grunn. ${ }^{135}$ På denne bakgrunn kan det nok reises tvil om kommisjonens forslag blir fulgt opp i den videre lovbehandlingen.

Også den foreslåtte tredelingen av straffebudene etter handlingens grovhet fremstår som hensiktsmessig. ${ }^{136} \AA$ gradere ulike strafferammer for ulike handlinger i forhold til hverandre er, som kommisjonen fremhever, en vanskelig oppgave. De retningslinjer som er oppstilt i så måte, synes imidlertid hensiktsmessige. ${ }^{137}$

Selv om jeg i det vesentlige er enig i kommisjonens vurderinger om strafferammene, har jeg også enkelte innvendinger. For det første er jeg kritisk til kommisjonens skepsis mht. at lovgiver skal styre straffutmålingen. Selv om kommisjonen særlig synes å ha for øye at lovgiver skjerper strafferammene for at domstolene skal idømme strengere straff, er den generelle uttalelsen som er gjengitt ovenfor problematisk.

Det har i flere år pågått en debatt i Norge om og i tilfelle hvordan Stortinget kan påvirke domstolene mht. straffutmålingen. ${ }^{138}$ Det er ingen tvil om at Stortinget i egenskap av lovgiver er i sin fulle rett til å styre straffenivået. Ønsker man å heve straffenivået, kan det vedtas minstestraffer. Og dersom man ønsker å senke straffenivået $\mathrm{i}$ forhold til straffebud som har minstestraff, kan man oppheve disse. ${ }^{139}$ Et annet virkemiddel er å heve strafferammen samtidig som man i forarbeidene gir uttrykk for at lovendringen er begrunnet i et ønske om å heve det generelle straffenivået. ${ }^{140} \mathrm{Om}$ en slik lovendring faktisk vil få betydning, vil bero på domstolenes lojalitet overfor lovgiver. ${ }^{141}$ Endelig kan det 
foretas en detaljregulering av straffenivået slik som man har i promillesaker etter endringen i 1988. ${ }^{142}$ Det kontroversielle spørsmålet er om Stortinget, når det opptrer utenfor lovgiverrollen, kan påvirke straffenivået.

Vi har mange eksempler fra de senere år hvor politikere har gitt uttrykk for misnøye med det etablerte straffenivået. Dette har dels kommet frem i budsjettinnstillinger og andre innstillinger i Stortinget, dels ved at enkeltstående stortingsrepresentanter har gitt utrykk for slike standpunkt. Med utgangspunkt i maktfordelingslæren kan ikke slike uttalelser ha noen bindende effekt på domstolene. Ikke engang plenumsvedtak i Stortinget om at straffenivået bør heves for visse overtredelser, kan binde domstolene. ${ }^{143}$

Selv om Stortinget bare kan binde domstolene når det opptrer som lovgiver, er det likevel spørsmål om ikke domstolene bør ta inn over seg de politiske signaler som kommer i andre sammenhenger. ${ }^{144}$ Det er her grunn til å understreke at domstolene ikke kan opptre som om de lever i et politisk vakuum - det må være et samspill mellom Stortinget og domstolene. ${ }^{145}$ Dersom domstolene fullstendig ignorerer signaler, vil de innlede en kamp som de er nødt for å tape. Lovgiver har siste ord mht. hvilket straffenivå vi skal ha, noe som kan gjennomtvinges for eksempel ved å innføre minstestraffer eller på annen måte detaljstyre straffutmålingen. Og dersom domstolene undergraver minstestraffer ved i stor utstrekning å gjøre straffen betinget, vil et mottrekk fra lovgiver være å innskrenke adgangen til å gi betinget dom.

Selv om jeg prinsipielt mener at domstolene bør ta hensyn til de signaler som kommer fra Stortinget enten det skjer i egenskap av lovgiver eller ikke, medfører et slikt standpunkt nye utfordringer. En for stor vektlegging av signaler kan medføre at straffenivået kan variere etter det til enhver tid sittende flertall på Stortinget. Domstolene må søke å ivareta de lange linjer i strafferettspleien. ${ }^{146} \mathrm{Et}$ annet problem er at uttalelser fra politikere som regel er bygget på manglende kunnskap om det faktiske straffenivå. ${ }^{147}$ Dette ser man tydelig når lekdommere gjerne går inn for en lavere straff enn det som er etablert i høyesterettspraksis. ${ }^{148}$ Selv om altså domstolene bør ta hensyn til de holdninger som gjør seg gjeldende i samfunnet, er det en vanskelig oppgave når disse i så stor grad gjerne er bygget på et mangelfullt fundament. Dette tilsier at domstolene under alle omstendigheter bør være varsomme, og at man primært legger vekt på signaler som er bygget på riktige faktiske forutsetninger.

Når det skal utferdiges en ny straffelov, finner jeg det uansett temmelig opplagt at lovgiver har det overordnede ansvaret for straffenivået. Dette kan medføre fare for at man av populistiske grunner får et strengere straffenivå enn det som faglig sett er begrunnet. Men ansvaret for dette påligger lovgiver og ikke domstolene. De fagpersoner som står utenfor den politiske strid - herunder dommere, representanter fra påtalemyndigheten, advokater og forskere - må redegjøre for det etablerte straffenivå og hvilke - manglende - virkninger en heving av straffenivået mest sannsynlig vil få. På denne måten kan man bidra til å 
avklare det faktiske grunnlaget for fastsettelsen av strafferammen.

Selv er jeg generelt kritisk til å heve det generelle straffenivået. For enkelte handlinger kan det nok være grunnlag for visse justeringer: Ved enkelte sedelighetsforbrytelser kan det være rom for en ytterligere skjerpelse, ${ }^{149}$ mens det for narkotikaforbrytelsene - som også kommisjonen foreslår ${ }^{150}$ - er grunn til å justerer nivået ytterligere ned. ${ }^{151}$ Etter min vurdering går imidlertid Straffelovkommisjonen for langt når den foreslår en maksimumsstraff på 10 år for narkotikaforbrtyelse. En strafferamme på 15 år bør imidlertid være tilstrekkelig. ${ }^{152}$

Kommisjonen er etter min mening med rette kritisk til minstestraffer. ${ }^{153}$ Slike kan som ytterste konsekvens medføre at domstolene frikjenner den tiltalte fordi minstestraffen i det konkrete tilfellet vil slå særdeles uheldig ut. Flertallet vil som nevnt beholde minstestraff for drap og grove seksuelle overgrep mot barn. For slike handlinger er jeg enig $\mathrm{i}$ at det er hensiktsmessig å gi en klar verdimarkering $\mathrm{i}$ form av en minstestraff. ${ }^{154}$ Mindretallets synspunkt om at det kan være vanskelig å forutse alle relevante omstendigheter i forhold til disse handlinger, synes overdrevet. Så lenge man begrenser minstestraffene til de nevnte forhold, vil man neppe få urimelige resultater. Man har tross alt en meget lang erfaring med minstestraff for drap uten at dette synes å ha skapt særlige problemer i praksis.

I utkastet til § 6-3 foreslår som nevnt flertallet i kommisjonen at maksimumsstraffen for personer under 18 år på gjerningstidspunktet settes til 8 års fengsel. En tilsvarende maksimumstraff er fastsatt i dansk rett, jfr. dstrl. $\S 84$ stk. 1 nr. 2. Også Sverige har regler som søker å begrense bruken av fengselsstraff overfor personer under 18 år, se BrB 26 kapittel $3 \S$ som bestemmer at reglene om gjentakelsesstraff ikke får anvendelse overfor personer under 21 år, og BrB 29 kapittel $§ 7$ bestemmer at livstidsstraff ikke kan idømmes overfor personer som var under 21 år på gjerningstidspunktet. Sammenholdt med BrB 26 kapittel $1 \S$ jfr. $2 \S$, blir maksimumsstraffen for denne aldersgruppen fjorten år, men slik at det skal tas særlig hensyn til ung alder ved straffutmålingen, se BrB 29 kapittel $\S 7$. Det er ikke vanskelig å være enig i flertallets generelle syn på bruken av fengselsstraff overfor unge lovbrytere. ${ }^{155}$ I rettspraksis ser man også at domstolene er svært tilbakeholdne med å idømme ubetinget fengsel overfor personer under 18 år. ${ }^{156}$ Jeg er likevel enig med mindretallet som går imot en slik maksimumsstraff, og i stedet vil gå inn for en strafferamme på 15 år. ${ }^{157}$ Ved konkurrens vil også dette være en reduksjon i forhold til gjeldende rett. Mitt standpunkt er begrunnet $\mathrm{i}$ at det forekommer tilfeller hvor helt unge personer begår meget alvorlige forbrytelser. Som eksempel kan det vises til den såkalte Baneheiasaken hvor to unge gutter hadde voldtatt og drept to mindreårige piker. Den yngste av de tiltalte var litt over 19 år da handlingen ble begått. Straffen ble fastsatt til 19 års fengsel, jfr. Rt. 2002 s. 993 . Et annet eksempel finner man i Rt. 2003 s. 247 hvor en gutt som var $18^{1 / 2}$ år på gjerningstidspunktet, uten foranledning hadde slått $\mathrm{i}$ hjel en kamerat med fire 
øksehugg mot hodet, og en uke etter drapet parterte han liket som han hadde plassert på sitt bad. Straffen ble fastsatt til 14 års fengsel. Dersom de tiltalte i disse sakene hadde vært like under 18 år, tror jeg med Straffelovkommisjonens mindretall at det ville støte an mot alminnelige folks rettsfølelse om domstolene skulle være bundet til å utmåle en straff på maksimalt 8 års fengsel. Selv om man altså bør være tilbakeholden med å idømme streng straff overfor unge lovbrytere, er det uheldig å ha en slik absolutt regel som flertallet foreslår.

Flertallet i kommisjonen foreslår for øvrig et forbud mot at det idømmes forvaring overfor personer under 18 år, se utkastet til § 11-1 tredje ledd jfr. NOU 2002: 4 s. 252 første spalte jfr. s. 253 andre spalte. Også på dette punkt tror jeg det er uheldig å ha et absolutt forbud, slik også Slettan TfS 2002 s. 382. Som mindretallet fremhever, vil vilkårene for forvaring sjelden være oppfylt overfor så unge lovovertredere. Men dersom vilkårene først er oppfylt, må samfunnet ha rett til å beskytte seg mot gjentatte forbrytelser mot liv og helse, se NOU 2002: 4 s. 253-254. Flertallet i kommisjonen foreslår for øvrig forbud mot å varetektsfengsle lovbrytere under 16 år, se NOU 2002: 4 s. 237 første spalte jfr. s. 467-468. Mindretallet går også her imot et absolutt forbud - se NOU 2002: 4 s. 468 - noe jeg er enig i. Det må understrekes at varetektsfengsling av så unge personer hører til sjeldenheten. I praksis er det dertil stilt særlig strenge krav til begrunnelsen om at fengslingen må være nødvendig når det er tale om svært unge personer, se strpl. § 170 a jfr. Rt. 2003 s. 333 og 2003 s. 451 . Men fengsling kan i unntakstilfeller fremstå som en siste utvei. Av denne grunn er det uheldig å fullstendig avskjære muligheten for å ta et slikt virkemiddel i bruk.

Selv om jeg på enkelte punkter er uenig med flertallet i kommisjonen, mener jeg som nevnt at det ikke er påkrevd med noen generell skjerpelse av straffenivået i Norge. En slik skjerpelse vil være i strid med den norske kriminalpolitiske tradisjon. Lundutvalget som har gjennomgått straffebudene til vern om rikets sikkerhet, har gitt følgende beskrivelse av norsk strafferettspleie:

«Den norske strafferettstradisjon, som senere år er kommet under press fra krav om strengere straffereaksjoner og mer inngripende metoder i kriminalitetsbekjempelsen, er et meget verdifullt element i det norske samfunn. Strafferettstradisjonen gjenspeiler i ikke liten grad et samfunns sivilisatoriske og humanistiske nivå ved å vise den maktbruk og de metoder samfunnet ser seg tjent med og berettiget til å bruke mot dem som krenker samfunnets normer. Dette inngår i det alminnelige verdigrunnlag et samfunn bygger på og som påvirker holdninger og atferd. En mild og human strafferettspleie vil i dette perspektiv generelt kunne være egnet til å dempe kriminalitetsnivået.» NOU 2003: 18 s. 62 første spalte.

Dette er et syn som jeg deler. De mange forslag fra Straffelovkommisjonen som innebærer en reduksjon av strafferammene for at de skal være bedre tilpasset det etablerte nivået bør derfor hilses velkommen. Derimot er det å beklage at Justisdepartementet i høringsbrevet om Straffelovkommisjonens utredning, datert 13. juni 2002 har bedt om høringsinstansenes syn på om strafferammen ved sammenstøt av forbrytelser bør heves til 30 år. Maksimumsstraffen er i dag 21 års fengsel hvor dette er særlig bestemt, se strl. § 17 første ledd litra (b). Departementet begrunner forslaget med at det kan virke støtende på den alminnelige 
rettsfølelse dersom en gjerningsperson som har begått en forbrytelse som kvalifiserer for 21 års fengsel, på nytt begår en straffbar handling før den første er pådømt. Ved straffutmålingen vil man da ikke kunne fange opp at det er begått flere alvorlige forbrytelser. En slik situasjon vil neppe foreligge ofte. Når departementet $\mathrm{i}$ tillegg åpent erkjenner at det av hensyn til de preventive virkninger neppe er noe å hente ved å skjerpe straffen fra 21 til 30 år, er det grunn til å reise spørsmål ved hva som overhodet er formålet med en slik endring. ${ }^{158}$ Forslaget fremstår derfor som faglig sett ubegrunnet. Derimot er dagens maksimumsstraff på 21 år som ble innført ved lov av 12. juni $1981 \mathrm{nr} .62 \mathrm{i}$ anledning avskaffelsen av livstidsstraffen, et resultat av en grundig vurdering. ${ }^{159}$ Det fremstår derfor som uforståelig at departementet i sitt høringsbrev legger til grunn at maksimumsstraff på 21 år kom inn i loven uten noen utdypende begrunnelse.

Beholder man maksimumsstraffen på 21 år, må man leve med at taket på 21 år nås, uten at det er mulig å fingradere straffen sammenlignet med andre mindre grove forbrytelser som likevel også fortjener 21 års fengsel: Et drap kan i seg selv kvalifisere til 21 års fengsel, mens det for et trippeldrap ville blitt fastsatt en strengere straff dersom loven hadde gitt anledning til det. Straffelovkommisjonen uttaler riktignok at man ved fastsettelsen av øvre strafferamme må ta høyde for at det kan forekomme grovere tilfeller enn de groveste man kjenner fra rettspraksis. ${ }^{160}$ Dette synspunktet er jeg i utgangspunktet enig i, men det bør fravikes når man nærmer seg den maksimumsstraffen som samfunnet alt $\mathrm{i}$ alt har funnet akseptabel. ${ }^{161}$

Dersom man skal heve maksimumsstraffen til 30 år, risikerer vi å komme i samme situasjon som man har hatt ved narkotikaforbrytelser. Etter hvert som man har nådd taket, har man flyttet grensen oppover for å ta høyde for grovere tilfeller. ${ }^{162}$ I sum vil dette medføre en spiral med stadig strengere maksimumsstraff. Da er spørsmålet hvorfor departementet havnet på akkurat 30 år. Ut fra den manglende faglige begrunnelse kunne man like godt foreslått 35 eller 40 år. Men et slikt forslag vil man kanskje spare til senere?

På denne bakgrunn er det lett å være enig med Lundutvalget som legger til grunn at en hevning av maksimumsstraffen ut fra de betraktninger departementet har gjort gjeldende, vil medføre et brudd med norske rettstradisjoner som det ikke kan slutte seg til. ${ }^{163}$

\subsection{Hvilke straffbare handlinger bør tas inn i straffeloven - forholdet til sarlov- givningen}

Straffeloven av 1902 tok mål av seg å være uttømmende, og da den ble vedtatt var det relativt få straffebud $i$ andre lover. Utviklingen av samfunnet har imidlertid medført at flertallet av straffebudene i dag er å finne utenfor straffeloven, dvs. i spesiallovgivningen. ${ }^{164}$ Straffelovkommisjonens mandat omfattet å vurdere om det var grunn til å opprettholde alle straffebestemmelser i spesiallov- 
givningen, og/eller om noen av bestemmelsene burde overføres til straffeloven. Som følge av justeringen av mandatet i 1994, har imidlertid ikke kommisjonen foretatt en gjennomgang av spesiallovgivningen. Kommisjonen er likevel av den oppfatning at antallet straffebud i spesiallovgivningen kan reduseres og erstattes med andre sanksjoner. Fortsatt vil det imidlertid i betydelig grad være behov for straffebestemmelser i spesiallovgivningen slik at det ikke vil bli tale om å samle alle straffebud i straffeloven. Kommisjonen oppstiller imidlertid noen retningslinjer og momenter som bør tillegges betydning ved plassering av straffebud $i$ henholdsvis straffeloven og spesiallovgivningen. ${ }^{165}$

For det første må man ta hensyn til handlingens grovhet. De mest graverende handlinger bør plasseres i straffeloven. Ved avgjørelsen av om en handling er alvorlig, kunne man tenke seg å bygge på strafferammen. Men siden en rekke straffebud gir adgang til å idømme frihetsstraff, er det ikke hensiktsmessig å samle alle disse i straffeloven. Dette kunne også medføre at straffebud blir tatt ut fra den saklige sammenheng hvor de hører hjemme. Dertil er det ikke gitt at de gjeldende strafferammer avspeiler nåtidens vurdering av handlingens straffverdighet. ${ }^{166}$ Straffeloven burde imidlertid som hovedregel inneholde alle straffebud som kunne medføre fengsel $\mathrm{i}$ inntil 6 år. Kommisjonen foreslår derfor at bestemmelsene om skattesvik, grov alkoholovertredelse og reglene om innsidehandel inntas i den nye straffeloven. ${ }^{167}$

I forlengelsen av hvilke straffebud som burde inntas i straffeloven vurderte kommisjonen om straffebud med laveste strafferamme burde overføres til spesiallovgivningen. Kommisjonen fant det vanskelig å operere med en slik hovedregel, men spørsmålet burde vurderes $i$ lys av de øvrige forhold som er relevante ved plassering av straffebud i henholdsvis straffeloven eller spesiallovgivningen, se NOU 2002: 4 s. 159-160.

Det andre forhold som kan ha betydning for plasseringen, er hvilken type interesse som straffebudet verner. Det er blitt anført at straffeloven tradisjonelt har vernet individuelle interesser, mens mer allmenne samfunnsinteresser som miljøvern etc. har vært henvist til spesiallovgivningen. ${ }^{168}$ Straffelovkommisjonen reiste spørsmål om det var grunnlag for å sondre mellom offentlige og private interesser. Mange av straffebudene som tilsynelatende tar sikte på å verne private interesser vil også i realiteten verne offentlige interesser. Uansett fant kommisjonen at sondringen mellom offentlige og private interesser ikke burde ha betydning for om et straffebud ble plassert i straffeloven eller ikke. ${ }^{169}$

For det tredje reiste kommisjonen spørsmål om plasseringen kunne ha en symbolvirkning fordi folk flest kunne oppleve det som mer alvorlig å bli dømt etter en bestemmelse i straffeloven enn en bestemmelse i spesiallovgivningen. Kommisjonen påviste at symboleffekten var tillagt forskjellig betydning i lovgivningspraksis. Noen ganger, for eksempel ved innføringen av strl. § $152 \mathrm{~b}$ om miljøkriminalitet, er det anført at plasseringen i straffeloven kan virke som et signal om at slike handlinger er alvorlige. Andre ganger er det anført at en 
særlov vil være en klar markering fra lovgiver om handlingens forkastelighet, se for eksempel lov om forbud mot kjønnslemlestelse av 15. desember $1995 \mathrm{nr} .74$ - en lov som kommisjonen for øvrig foreslår opphevet da de aktuelle handlinger rammes av de generelle bestemmelser om legemskrenkelser i straffeloven. ${ }^{170}$ Kommisjonen fremhevet at straffebudenes plassering nok var ukjent for de fleste. Straffen ville nok ha en viktigere symboleffekt enn hvor straffebudet var plassert. Når det dertil var vanskelig å påvise en enhetlig linje, burde ikke dette hensynet tillegges betydning ved plassering av straffebud i henholdsvis straffeloven eller spesiallovgivningen. ${ }^{171}$

Som et fjerde hensyn reiste kommisjonen spørsmål om plasseringen kunne ha allmennpreventive virkninger ved at straffebud i straffeloven ble bedre kjent overfor potensielle lovbrytere. ${ }^{172}$ Straffelovkommisjonen la imidlertid til grunn at plasseringen ikke hadde nevneverdig betydning i så måte. Særlovgivningen retter seg ofte mot bestemte grupper i samfunnet, og det måtte legges til grunn at disse $\mathrm{i}$ en viss utstrekning satte seg inn i det aktuelle lovverket. Straffesanksjoner for overtredelser av særlovgivningen måtte derfor antas å bli bedre kjent for dem de berørte om de fremgikk av den aktuelle lovgivningen fremfor at man måtte slå opp i straffeloven. Kommisjonen fant derfor at hensynet til å gjøre straffebud kjent, etter omstendighetene kunne være et argument for å plassere dem i særlovgivningen, mens det var mindre relevant å legge vekt på tilgjengelighet og allmennpreventive virkninger ved avgjørelsen av om en bestemmelse skulle inntas i straffeloven. ${ }^{173}$

For det femte fremhevet kommisjonen at straffebudenes plassering burde ses i en saklig sammenheng: Regler som saklig hører sammen bør stå i samme lov. ${ }^{174}$ Normalt vil en straffetrussel for overtredelse av spesiallovgivningen ha saklig sammenheng med de enkelte bestemmelser i den aktuelle lov. På den andre siden kan straffetrusselen også ha sammenheng med bestemmelser som bør plasseres i straffeloven: ${ }^{175}$

«Når straffeloven har et eget kapittel for straffebud til vern om en bestemt interessetype, er
det mulig å ivareta hensynet til saklig sammenheng selv om et straffebud overføres fra
særlovgivningen til straffeloven. På den annen side vil mangelen på et passende kapittel i
straffeloven kunne trekke i retning av å plassere eller beholde en straffetrussel i særlovgiv-
ningen. Forutsetningen for en eventuell overføring fra straffeloven må imidlertid være at
det finnes en særlov hvor bestemmelsen passende kan plasseres.» NOU 2002: $4 \mathrm{~s}$. 162-163.

Oversiktlighet ved at bestemmelser som saklig hører sammen plasseres i samme lov, måtte etter kommisjonens vurdering være et tungtveiende moment ved avgjørelsen av om straffebud skulle inntas i straffeloven. Likevel var det vanskelig å si noe generelt om vekten av dette hensynet, og det enkelte straffebud måtte vurderes for seg. ${ }^{176}$

Et sjette forhold som ble trukket frem var at plasseringen kunne ha lovtekniske implikasjoner. Straffebud som inntas i straffeloven blir gjerne gjen- 
stand for en mer inngående vurdering enn en straffetrussel som henges på en særlov. Justisdepartementets lovavdeling har ansvaret for straffeloven, mens særlovgivningen er overlatt til ulike departement som også ivaretar andre oppgaver enn å utforme lover og straffebestemmelser:

«... plassering av et straffebud i straffeloven [vil] gjennomgående innebære en mer kvalifisert vurdering av selve kriminaliseringsspørsmålet, reaksjonsvalget, strafferammen, skyldkravet og forholdet til straffelovens alminnelige del enn det som er tilfelle med straffebud $\mathrm{i}$ særlovene.» NOU 2002: 4 s. 163 første spalte.

I tillegg vil man gjerne finne at straffebud i særlovgivningen rammer likeartede handlinger, men på forskjellige livsområder. Typiske eksempler er brudd på taushetsplikt, utøving av virksomhet uten nødvendig tillatelse mv. Slike bestemmelser er gjerne dårlig harmonisert for så vidt gjelder skyldkrav og andre sentrale strafferettslige spørsmål. ${ }^{177}$ Kommisjonen fremhevet at man burde søke å unngå forskjeller i utformingen av straffebud som rammet likeartede handlinger. En måte å løse dette problemet var å innføre standardstraffetrusler i straffeloven som inneholdt de sentrale vilkår for straff, slik at man i særlovgivningen kunne vise til denne bestemmelsen. Som eksempel på en allerede eksisterende bestemmelse av denne type, kan det vises til strl. § $121 \mathrm{om}$ brudd på taushetsplikt for offentlige tjenestemenn. ${ }^{178}$

Som et syvende forhold kunne det reises spørsmål om plasseringen hadde betydning for den kriminalpolitiske innsatsen ved at man knyttet mer ressurser til bekjempelse av handlinger som er kriminalisert i straffeloven fremfor i spesiallovgivningen. ${ }^{179}$ Kommisjonen mener imidlertid at plasseringen ikke har nevneverdig betydning for den kriminalpolitiske innsats. Dette skyldes dels at kriminalpolitikken spiller en helt annen rolle i dagens samfunn enn den gjorde da straffeloven av 1902 ble vedtatt. ${ }^{180}$ Hvor straffebudene er plassert, har derfor neppe noen selvstendig betydning i så måte. ${ }^{181}$

Som et siste forhold det kunne være relevant å legge vekt på, fremhevet kommisjonen det forhold at et straffebud tradisjonelt har vært inntatt i straffeloven. Men i forhold til enkelte bestemmelser som kan føres langt tilbake i straffelovgivningen, kunne hensynet til saklig sammenheng likevel tilsi at de ble flyttet til en spesiallov. Som eksempel nevner kommisjonen strl. § $400 \mathrm{om}$ forbud mot plukking av multer i multeland. Denne bestemmelsen kunne det være mer naturlig å plassere i friluftsloven av 28. juni $1957 \mathrm{nr} .16 .{ }^{182}$ Selv om tradisjonelle hensyn kunne tilsi at et straffebud ble plassert der brukerne var vant med å finne det, måtte man ved en gjennomgripende reform stille seg relativt fritt mht. tradisjonen. Hensynet til tradisjonen kunne derfor bare være et selvstendig moment hvor øvrige hensyn ikke talte for å flytte et straffebud til en annen lov. ${ }^{183}$

De retningslinjer som kommisjonen her har gitt, er etter mitt syn hensiktsmessige. Det kan selvsagt være uenighet om hvor enkelte straffebud skal plasseres. For eksempel synes jeg at hensynet til saklig sammenheng kan tilsi at 
både reglene om promillekjøring, innsidehandel og overtredelser av alkoholloven, like gjerne kan beholdes i den enkelte særlov fremfor å overføre dem til straffeloven.

\subsection{Andre generelle endringer}

3.5.1. Endringer i den materielle strafferett

Straffelovkommisjonen av 1994 har et annet syn på noen sentrale spørsmål innenfor den alminnelige del sammenlignet med kommisjonen av 1980. Blant annet av denne grunn er det et eget kapittel i utredningen hvor man tar opp forholdet til utredningen fra 1991. I det helt vesentlige er imidlertid de to utkast sammenfallende.

Av formelle ting har kommisjonen av 1994 foretatt en annen inndeling av loven sammenlignet med utkastet fra $1991 .{ }^{184}$ Videre er det foreslått en to-leddet paragrafnummerering - $\$ 1$ i 1991 -utkastet er blitt til $\S 1-1$ i 2002-utkastet. ${ }^{185}$

Kommisjonen opprettholder det tidligere forslag om å oppheve sondringen mellom forbrytelser og forseelser. Selv om det kan virke mindre belastende å bli dømt for en forseelse, vil ikke sondringen alltid avspeile en reell forskjell $i$ handlingens alvor. Som et felles uttrykk foreslås det at man i stedet bruker begrepet «straffbar handling». Hvor det er behov for å uttrykke at bare de objektive vilkår etter straffebudet er oppfylt, brukes uttrykket «overtredelse». Begrepet «forbrytelse» er reservert de tilfeller hvor det er tale om meget alvorlige handlinger og hvor begrepsbruken er vel innarbeidet, for eksempel krigsforbrytelser og forbrytelser mot menneskeheten. ${ }^{186}$

I tråd med kommisjonens grunnsyn om at det bør vises tilbakeholdenhet med å bruke straff, foreslås det som nevnt at utgangspunktet er at overtredelser bare skal være straffbare i sin forsettlige eller grovt uaktsomme form. Kommisjonen foreslår for øvrig å standardisere skyldkravene i straffeloven. Det generelle skyldkravet er forsett, jfr. strl. $\S 40$, men slik at uaktsomhet straffes når dette er særskilt nevnt i det enkelte straffebud. Noen straffebud har likevel en avvikende formulering av skyldkravet, uten at dette nødvendigvis medfører at man har ment å fravike det som ellers kan utledes av forsetts- eller uaktsomhetsbegrepet, se for eksempel strl. $\S \S 155$ (uaktsomhet) og 139 (skjerpet forsettskrav). ${ }^{187}$ Kommisjonen har derfor lagt opp til at man så vidt mulig bare bør bruke skyldkravene forsett og uaktsomhet. Dessuten foreslås det at det skjerpede skyldkrav om hensikt som hovedregel utgår fra staffeloven. ${ }^{188}$ At kravet til hensikt utgår, vil særlig ha betydning i forhold til vinningsforbrytelsene. ${ }^{189}$ For tyveri vil den foreslåtte endringen medføre at den norske loven blir sammenfallende med dansk og svensk rett, se dstrl. § 276 og BrB 8 kapittel $1 \S$. Ved enkelte forberedelseshandlinger er det etter kommisjonens mening likevel grunn til å begrense straffebudets virkeområde gjennom krav om en bestemt hensikt. ${ }^{190}$

Etter norsk rett kan man ikke fingere hensikt dersom siktede var bevisstløs 
som følge av selvforskyldt rus. ${ }^{191}$ Men i forhold til forsett vil den bevisstløse bli bedømt som om han var edru. Teoretisk sett kan fjerning av kravet til vinnings hensikt medføre en viss nykriminalisering. Også i forhold til uaktsom villfarelse som ellers utelukker krav om hensikt, vil forslaget kunne medføre en nykriminalisering..$^{192}$

For øvrig foreslås det også at andre varianter av skyldkrav som inneholder krav om en bestemt hensikt utgår, for eksempel krav om rettsstridig hensikt og skadehensikt. ${ }^{193}$ Her er det grunn til å merke seg at kommisjonen foreslår en generell regel om innskrenkende tolkning, jfr. utkastet til § 3-7, som dermed både erstatter begrensninger i straffebudet som i dag er angitt ved særlige skyldkrav og den generelle, til dels ulovfestede, rettsstridsreservasjonen.

Også hensiktskrav i enkelte regler om straffrihet, foreslås opphevet. ${ }^{194}$ Selv om krav om hensikt som hovedregel utgår som skyldkrav, vil imidlertid hensikten kunne få betydning for straffutmålingen. ${ }^{195}$

Overlegg er ikke et selvstendig skyldkrav i straffeloven i dag, men kun et straffskjerpende forhold, jfr. strl. $\S \S 231$ (grov legemsbeskadigelse) og 233 (drap). Kommisjonen mener imidlertid at skyldformen helt bør utgå av loven. Om det foreligger overlegg, skal i stedet ha betydning for vurderingen av om det foreligger en grov overtredelse. ${ }^{196}$

Straffelovkommisjonen av 1980 foreslo i sin utredning å fjerne den særlige skyldformen culpa levissima, jfr. strl. $\S 43$ hvoretter strafferammen forhøyes når en handlig har hatt uforsettlige, men forutselige følger. ${ }^{197}$ Høringsinstansene var stort sett negativ til dette forslaget. Straffelovkommisjonen av 1994 opprettholder likevel forslaget:

«... Etter kommisjonens syn er det urimelig at strafferammen økes som følge av konsekvenser av den straffbare handlingen som gjerningspersonen ikke engang burde ha innsett muligheten av.» NOU 2002: 4 s. 178 andre spalte.

Dersom den forsettlige handlingen har medført følger som kan tilregnes gjerningspersonen som uaktsomme, mener imidlertid kommisjonen at følgen i visse tilfeller bør kunne medføre en skjerpet reaksjon. Kommisjonen var derimot ikke enig i forslaget om at alle regler om forhøyet strafferamme ved uforsettlige følger burde oppheves, uavhengig av hvilken uaktsomhet som var utvist. Men i motsetning til straffeloven av 1902 skal ikke uforsettlige følger uten videre medføre en høyere strafferamme. For det første er det i utkastet til § 3-11 første punktum oppstilt krav om at gjerningspersonen har opptrådt uaktsomt i forhold til følgen. For det andre er det i utkastet til § 3-11 andre punktum forutsatt at det samme kravet skal gjelde dersom uforsettlige følger inngår i en konkret helhetsvurdering av om handlingen må anses som grov. ${ }^{198}$

Skyldformen dolus eventualis har hatt en bemerkelsesverdig skjebne i Straffelovkommisjonens arbeid. I norsk rett er det bare den positive innvilgelsesteori som er anerkjent, jfr. Rt. 1991 s. 600 og 2001 s. $58 .{ }^{199}$ I prinsipputredningen fra 
1983 var det foreslått at denne skyldformen skulle utgå. ${ }^{200}$ Etter å ha vurdert spørsmålet på nytt, fant imidlertid kommisjonen at det likevel var grunn til å beholde dolus eventualis i form av den positive innvilgelsesteori da utkastet til alminnelig del ble fremlagt i $1991{ }^{201}$ Flertallet $\mathrm{i}$ kommisjonen av 1994 kom imidlertid til at det ikke var grunn til å beholde denne skyldformen. Ut over synspunktene i delutredningen fra 1983 og innvendingene som det var redegjort for i forslaget fra 1991, fremhevet flertallet at også den positive innvilgelsesteori inneholder et hypotetisk element, de betydelige bevisproblemer som ofte oppstår og de store problemene man har hatt med å formulere bevistemaet tilstrekkelig presist. ${ }^{202}$

$\AA$ utforme selve bevistemaet presist, er neppe det største problemet i tilknytning til dolus eventualis. Dette gjelder enten man velger den formen som er lagt til grunn i rettspraksis, eller den innskjerpelsen som er forutsatt i utredningen fra $1991 .{ }^{203}$ Selv om det kan anføres at skyldformen har mindre betydning, er det ikke tvil om at det finnes tilfeller hvor det klart nok kan være behov for dolus eventualis. ${ }^{204}$ Kommisjonen fra 1980 anførte at å fjerne dolus eventualis kunne medføre at man oppstilte et mindre strengt beviskrav ved sannsynlighetsforsett, slik at det i praksis kan bli domfellelse selv om følgen ikke fremsto som overveiende sannsynlig. ${ }^{205} \mathrm{Jeg}$ deler denne bekymring, og mener at dolus eventualis er et hensiktsmessig redskap for å skille tilfeller av bevisst uaktsomhet og det nedre sjiktet for forsett. Dertil kan en handling som er foretatt med dolus eventualis være like straffverdig som en handling som er foretatt med vanlig forsett eller sannsynlighetsforsett, jfr. Rt. 2000 s. 2072. Forsvareren anførte her at straffen måtte settes ned fordi det bare forelå dolus eventualis. Høyesterett avviste dette:

«... Etter mitt syn er handlinga ikkje ulikt straffverdig ut frå om domfelte sjølv plasserte narkotikaen i bilen eller om han let andre gjere det, vitande om at han ikkje hadde full kontroll med mengda han transporterte.» Rt. 2000 s. 2072 (s. 2073).

Dersom forslaget blir vedtatt, kan det medføre at man premierer narkotikaforbryteren som bevisst holder seg uvitende om hvilket stoff og kvantum han befatter seg med, men helt uavhengig av disse forhold likevel ville gjennomført handlingen. ${ }^{206}$ Dette vil også medføre at man i Norge avviker fra løsninger som er funnet akseptable $\mathrm{i}$ andre land som det er naturlig å sammenligne seg med. ${ }^{207}$

\subsubsection{Endringer i den prosessuelle strafferett}

Kommisjonen foreslår vesentlige endringer i påtalereglene. Mens gjeldende lov sondrer mellom straffebud som er underlagt 1) ubetinget offentlig påtale, 2) krever begjæring fra fornærmede eller 3) krever begjæring av fornærmede og/eller at allmenne hensyn krever det, ${ }^{208}$ vil fornærmedes begjæring etter kommisjonens forslag ikke være vilkår for påtale, verken alene eller sammen med allmenne hensyn. I stedet skal man sondre mellom straffebud som er underlagt 
ubetinget offentlig påtale og straffebud hvor påtalen er betinget av at allmenne hensyn krever det. ${ }^{209}$

Som begrunnelse for ikke å tillegge fornærmedes begjæring betydning, anfører kommisjonen at det uansett bare vil være ved et fătall straffbare forhold som det kan være aktuelt å stille krav om fornærmedes begjæring. Det vil dessuten ofte være tale om mindre alvorlige straffbare forhold. Hensynet til likhet og rettferdighet i strafferettspleien tilsier at den store hovedregel er ubetinget offentlig påtale. ${ }^{210} \mathrm{Krav}$ om påtalebegjæring fra fornærmede kunne åpne for at vedkommende ble utsatt for utilbørlig press fra gjerningspersonen for å unngå at forholdet ble påtalt. På den andre siden kunne avskaffelsen av reglene om fornærmedes begjæring medføre at man var avskåret fra å få en minnelig ordning hvor gjerningspersonen gjorde opp for seg mot at den fornærmede unnlot å begjære påtale..$^{211}$

Selv om fornærmedes begjæring ikke lenger skal være et vilkår for påtale, fremhever kommisjonen at fornærmede rent faktisk vil ha stor innflytelse på om det skal tas ut tiltale eller ikke. Overtredelser vil sjelden komme til politiets kjennskap med mindre fornærmede anmelder forholdet. Og dersom fornærmede under etterforskningen gir uttrykk for at vedkommende ikke ønsker forholdet påtalt, kan dette gi seg utslag i manglende medvirkning til å avklare det faktiske hendelsesforløp. Dette vil igjen kunne medføre at saken blir henlagt etter bevisets stilling. Sett i lys av ressurssituasjonen til politiet og påtalemyndigheten, er det i følge kommisjonen neppe grunn til å tro at straffesak i mindre alvorlige tilfeller blir reist i strid med fornærmedes ønsker. ${ }^{212} \mathrm{Og}$ hensynet til at strafferettsapparatet ved mindre alvorlige forhold bare bør aktiviseres når fornærmede ønsker det, kan ifølge kommisjonen ivaretas gjennom kravet om at påtale bare skjer dersom allmenne hensyn krever det. I denne vurderingen kan man ta hensyn til fornærmedes innstilling. ${ }^{213}$

Som kommisjonen selv fremhever, kan det være betenkelig å tillegge påtalemyndigheten en så vid kompetanse. Til dette anføres det at det synes som om adgangen til å henlegge saker når ikke allmenne hensyn krever påtale har vært utøvd på en hensiktsmessig måte. Det var grunn til å tro at dette også ville gjelde for fremtiden. Dertil foreslår kommisjonen å lovfeste momenter som inngår i vurderingen av om allmenne hensyn krever påtale. ${ }^{214}$ Dette skal sikre at det foretas en reell og saklig vurdering. Klageretten etter strpl. § 59 a vil også bidra til å sikre kvaliteten av vurderingen. ${ }^{215}$

Noen av høringsinstansene som avga uttalelse til delutredning I fra 1983 var kritiske til en slik regel. Dersom påtalemyndigheten fikk en så vid kompetanse, kunne saker med lav strafferamme henlegges pga. kapasitetsproblemer. Kommisjonen viste her til at man ville få formalisert adgangen til å henlegge saker av kapasitetsgrunner, jfr. utkastet til strpl. $\S 67$ syvende ledd, samtidig som denne adgangen ikke kunne benyttes når det var en kjent gjerningsperson. Dertil anførte kommisjonen at i tillegg til de retningslinjene som ville bli lovfestet 
for så vidt gjelder om det forelå allmenne hensyn, kunne man tenke seg at riksadvokaten ga nærmere instrukser om hvordan man skulle utøve skjønnet om allmenne hensyn krevde påtale. ${ }^{216}$ Foruten at det neppe kunne være særlig behov for å la fornærmedes innstilling være avgjørende for påtalespørsmålet, fant kommisjonen at også hensynet til å forenkle regelverket burde medføre at man ble stående med at påtalen $i$ fremtiden bare var ubetinget offentlig eller betinget av allmenne hensyn. ${ }^{217}$ Det er derfor ikke overraskende at kommisjonen også foreslår å oppheve regelen om at påtale i visse tilfeller er betinget av begjæring fra offentlig myndighet.

Ved valget mellom ubetinget offentlig påtale og påtale betinget av allmenn hensyn, fremhevet kommisjonen at betinget offentlig påtale bare kunne være aktuelt ved overtredelser med lav strafferamme. Dertil var det naturlig å se hen til hvilke interesser som var krenket ved overtredelsen. Allmenne hensyn ville være lettere å akseptere ved formueskrenkelser enn ved legemskrenkelser. Fornærmedes oppfatning burde imidlertid ha mindre betydning når handlingen i tillegg krenket offentlige interesser. Videre måtte man se hen til om den aktuelle overtredelsen kunne sanksjoneres gjennom sivilrettslige virkemidler som tvangsmulkt, erstatning etc. Også uheldig eksponering av offeret, for eksempel i saker om krenkelse av privatlivets fred, var et relevant moment $i$ avgjørelsen av hvilke overtredelser som burde være underlagt betinget offentlig påtale. Som det fremgår, mener kommisjonen at man skal foreta en sammensatt vurdering av om det skal være betinget offentlig påtale. Likevel foreslås det en generell regel om at handlinger som ikke kan medføre mer enn 2 års fengsel skal være underlagt slik påtale. ${ }^{218}$ For visse straffbare forhold medfører dette en utvidelse av hvilke handlinger som er underlagt ubetinget offentlig påtale sammenlignet med rettstilstanden i dag. ${ }^{219}$

På bakgrunn av at påtalereglene foreslås vesentlig forenklet, foreslås det å overføre de aktuelle bestemmelser til straffeprosessloven som ny strpl. $§ 62$ a. ${ }^{220}$

Kommisjonen foreslår videre å oppheve adgangen til å gå til privat straffesak. Forslaget må ses i sammenheng med forslaget om omlegging av påtalereglene. Straffelovkommisjonen fremhever at det reises få private straffesaker, og de sakene som reises er som regel saker om ærekrenkelse. Når kommisjonen samtidig foreslår vesentlige innskrenkninger i straffansvaret for ærekrenkelse, vil dette igjen føre til at enda færre saker enn i dag vil bli gjenstand for privat straffesak. På denne bakgrunn mener kommisjonen at tiden er moden for å avskaffe dette instituttet.

Tradisjonelt har adgangen til å gå til privat straffesak blitt ansett som en sikkerhetsventil eller et korrektiv til påtalemyndighetens skjønnsutøvelse. Dersom påtalemyndigheten ikke ønsker eller ikke har kapasitet til å forfølge forholdet, kan altså den fornærmede selv gjøre ansvaret gjeldende. ${ }^{221} \mathrm{Kom}$ misjonen mener at disse forhold ikke har særlig vekt i lys av adgangen til å påklage en henleggelse, jfr. strpl. §59 a, herunder adgangen til å bringe saken inn 
for sivilombudsmannen. Dertil har det vært anført at adgangen til å reise privat straffesak kan bli misbrukt av kverulanter: Den kan bli brukt for å skandalisere gjerningspersonen. ${ }^{222}$

$\AA$ oppheve adgangen til å reise privat straffesak er ingen ny tanke. I tilknytning til vedtakelsen av straffeprosessloven av 1981 fremmet flertallet i Straffeprosesslovkomiteen et tilsvarende forslag. ${ }^{223}$ Mindretallets standpunkt om å beholde ordningen ble imidlertid fulgt opp i den videre lovbehandlingen. ${ }^{224}$ Spørsmålet ble på nytt vurdert av Straffelovrådet i NOU 1995: 10. Her ble det foreslått å oppheve adgangen til å gå til privat straffesak om ærekrenkelser, men slik at krav om mortifikasjon skulle kunne fremmes etter sivilprosessens regler. ${ }^{225}$ Begrunnelsen var at det for fornærmede gjerne var av underordnet betydning at gjerningspersonen ble straffet, og slik at krav om oppreisning og mortifikasjon var tilstrekkelig til å ivareta vernet om æren. Leder av Straffelovrådet, professor dr. juris Henry John Mceland, hadde imidlertid en særuttalelse hvor han uttrykte skepsis mht. å oppheve instituttet, og anførte at alvorlige krenkelser burde forfølges strafferettslig. Han viste til at æren ville få et for svakt vern om gjeldende praksis med rutinemessig å henlegge saker om ærekrenkelser ble videreført når det eventuelt ikke var anledning til å reise privat straffesak. ${ }^{226}$

Siden det foreslås å oppheve sondringen mellom forbrytelser og forseelser, må det også foretas justeringer i reglene om kompetansefordelingen innen påtalemyndigheten mht. hvem som kan treffe påtalevedtak ved de ulike straffbare handlinger. Kommisjonen fremhever at den ikke vil foreslå vesentlige endringer $i$ dagens rettstilstand fordi dette ligger utenfor mandatet, og foreslår derfor først og fremst en lovteknisk tilpassing med utgangspunkt i forslaget om å oppheve sondringen mellom forbrytelser og forseelser. ${ }^{227}$

Man kunne her tenke seg at man knyttet påtalekompetansen til straffebudets strafferamme. Lovteknisk vil dette være enklest, men samtidig vil en slik ordning enten medføre en vesentlig innskrenkning eller en vesentlig utvidelse av politiets kompetanse sammenlignet med dagens ordning. Strafferammen kunne derfor ikke være det eneste kriteriet. Et alternativ var å supplere den generelle regel med unntaksbestemmelser. En slik ordning kunne medføre at man fikk en omfattende oppregning av bestemmelser som var unntatt fra lovens hovedregel, og dette kunne rettsteknisk være uheldig. Kommisjonen landet imidlertid på en slik løsning. ${ }^{228}$ Etter forslaget skal statsadvokaten ha påtalekompetanse ved straffebud med en strafferamme på mer enn 1 års fengsel, men slik at hovedregelen kombineres med delegasjonsbestemmelser som åpner for å tillegge politiet påtalekompetanse i saker som i utgangspunkt hører inn under statsadvokaten. Den nærmere avgrensning av politiets og statsadvokatenes påtalekompetanse vil derfor fremgå av påtaleinstruksen. ${ }^{229}$ For øvrig begrenses så vel politiets som statsadvokatenes påtalekompetanse av reglene som tillegger påtalekompetansen hos riksadvokaten eller Kongen i statsråd, se gjeldende strpl. §§ 64-65.

I Ot.prp. nr. 98 (2002-2003) er det foreslått at politiet skal ha påtalekom- 
petanse ved forseelser og forbrytelser som ikke kan medføre fengsel i mer enn 1 år, se utkastet til strpl. § 67 andre ledd litra a) og b). I tillegg har man i første ledd litra c) og d) listet opp en rekke forbrytelser hvor strafferammen overstiger 1 år, men hvor politiet likevel skal ha påtalekompetanse. Selv om opphevelsen av skillet mellom forbrytelser og forseelser først kan finne sted når en ny straffeloven trer i kraft, ser man altså allerede nå at de lovtekniske prinsippene som er lagt til grunn av kommisjonen, har fătt tilslutning hos departementet. Det aktuelle forslag vil ventelig bli behandlet høsten 2003.

De prosessuelle endringer som kommisjonen foreslår vil i sum medføre at fornærmedes stilling i straffeprosessen svekkes. For det første reduseres fornærmedes innflytelse over om det skal reises tiltale. Og når påtalekompetansen flyttes nedover i hierarkiet, blir avgjørelsen lagt på et nivå med en presumptivt lavere kompetanse enn om statsadvokatene skulle avgjort påtalespørsmålet. Rett nok har man som kommisjonen understreker, klageordninger mv. Spørsmålet er om dette er tilstrekkelig til å oppveie ulempene som endringene samlet sett medfører. ${ }^{230}$ Tar man i betraktning at kommisjonen dessuten foreslår å oppheve adgangen til privat straffesak, bortfaller også dette korrektivet til påtalemyndigheten. I lys av de senere års debatt hvor man har fokusert på ulike måter å styrke fornærmedes rolle i straffeprosessen, kan det synes underlig at kommisjonen går så vidt langt i motsatt retning uten at man drøfter spørsmålet i lys av denne utviklingen. ${ }^{231}$

Det kan også være grunn til å fremheve sammenhengen mellom avskaffelsen av private straffesaker og den i stor grad foreslåtte avkriminalisering av ærekrenkelser. ${ }^{232}$ Det er svært få tilfeller hvor det ilegges straff som følge av ærekrenkelser. Men de foreslåtte materielle endringer i straffebudene til vern om æren, kan også medføre en svekkelse av det erstatningsrettslige vern. ${ }^{233}$ Antall overtramp i pressen som krenker så vel æresfølelsen som privatlivets fred er neppe blitt færre siden 1902. A lempe på det strafferettslige ansvar kan i en slik situasjon være et uheldig signal. Hensynet til ytringsfriheten - herunder justering av grensen for de rettsstridige ytringer i lys av praksis fra Strasbourg ${ }^{234}-$ blir $^{2}$ etter mitt skjønn tilstrekkelig ivaretatt gjennom høyesterettspraksis. Under enhver omstendighet burde straffansvaret for ærekrenkelser vært drøftet $\mathrm{i}$ lys av våre konvensjonsforpliktelser hvoretter $\mathrm{FN}$-kovensjonen om sivile og politiske rettigheter av 1966 artikkel 17 (1) verner individet mot ulovlige angrep på æren eller omdømmet. Det er også grunn til å fremheve at det i praksis fra Strasbourg kan skje justeringer i synet på avveiningen mellom ytringsfrihet og vernet om æren. En slik utvikling kan medføre at æren blir ansett å ha et selvstendig vern gjennom EMK artikkel 8. ${ }^{235}$

3.6. Kommisjonens syn på enkelte spørsmål som lovgiver nylig har tatt stilling til I forhold til enkelte spørsmål som lovgiver nylig har tatt stilling til, har ikke kommisjonen veket tilbake for å legge en annen løsning til grunn for sitt forslag. 
Dette gjelder bl.a. i forhold til den fakultative straffritaksgrunnen om bevissthetsforstyrrelse ved selvforskyldt rus som ble avvist av Stortinget i $1997,{ }^{236} \mathrm{jfr}$. kommisjonens utkast til § 3-16 nr. 3.237

I forhold til forvaring, jfr. strl. $\S 39 \mathrm{c} \mathrm{nr}$. 1, foreslår kommisjonens flertall ${ }^{238}$ at man på nytt innfører et krav om at forvaring bare kan idømmes når gjerningspersonen tidligere har begått eller forsøkt å begå en alvorlig straffbar handling, til tross for at dette vilkåret ble fjernet ved ikrafttredelsesloven til forvaringsinstituttet, jfr. lov av 15. juni $2001 \mathrm{nr}$. $64 .{ }^{239}$ Jeg deler ikke kommisjonens standpunkt på dette punkt. Selv om bruk av forvaring reiser vanskelige vurderinger, har samfunnet rett til å beskytte seg mot farlige gjerningspersoner. Departementets begrunnelse for å fjerne kravet om at det må foreligge gjentatt overtredelse - en overtredelse kan vise at den aktuelle gjerningsperson er så farlig at det er behov for forvaring - er etter min mening forsvarlig. ${ }^{240}$

Straffelovkommisjonen har liten sans for bestemmelsen i strl. §34 a om utvidet inndragning som ble tilføyd ved lov av 11. juni 1999 nr. 39. Bestemmelsen pålegger i visse tilfeller den siktede å sannsynliggjøre at formuen han eier, er ervervet på lovlig måte. ${ }^{241}$ På dette punkt bøyer imidlertid kommisjonen seg for det valg som ble truffet i 1999. ${ }^{242}$ Det bør her fremheves at $\S 34$ a har sin parallell i mange andre lands lovgivning, og Menneskerettighetsdomstolen i Strasbourg har i Phillips v. The United Kingdom ${ }^{243}$ lagt til grunn at den tilsvarende engelske regulering ikke er i strid med uskyldspresumsjonen i EMK artikkel 6 (2). Flere internasjonale konvensjoner har for øvrig anbefalt statene å vurdere innført reguleringer som strl. §34 a, se senest United Nations Convention against Transnational Organized Crime av 15. november 2000 artikkel 12 nr. 7.

Strafferammen ved forbudet mot å bære våpen på offentlig sted, jfr. skissen til $\S 21-1,{ }^{244}$ foreslås til å være $\mathrm{i}$ det lavere sjikt. Ved å samle ulike overtredelser $\mathrm{i}$ samme bestemmelse, vil dette for de groveste overtredelser medføre en senking av strafferammen. Kommisjonen uttaler at den gjeldende vpl. $\S 33$ andre ledd som har en strafferamme på bot eller fengsel inntil 4 år, synes unødvendig streng. Det er grunn til å understreke at de aktuelle strafferammer ble revidert så sent som i 1998, jfr. lov av 5. juni 1998 nr. 35. Rettspraksis viser at man i stor grad har fulgt opp straffskjerpelsen, se for eksempel Rt. 2003 s. 124. Bakgrunnen for skjerpelsen er at man har sett det som et alvorlig samfunnsproblem at stadig flere bringer med seg våpen på offentlige steder, og at de ofte er blitt tatt i bruk. Det er derfor ikke grunn til å tro at det vil bli vedtatt en strafferamme $\mathrm{i}$ det laveste sjikt, men en strafferamme på 2 år bør være tilstrekkelig.

Ved lov av 22. september $2000 \mathrm{nr}$. 79 ble promillegrensen for føring av motorvogn senket fra 0,5 til 0,2. Det er reist tvil om en senking av promillegrensen vil ha noen effekt på trafikksikkerheten. ${ }^{245}$ Kommisjonen sluttet seg derfor til en uttalelse fra riksadvokaten i anledning lovendringen i 2000 hvor det ble anført at en senking av promillegrensen kunne virke mot sin hensikt ved at mange bilførere som ikke ble oppfattet å utgjøre en trafikksikkerhetsrisiko, likevel ble 
straffet. Dette kunne i sin tur bidra til at man ufarliggjorde straffeforfølgning mot det som ble oppfattet som lavpromillekjøring. På denne bakgrunn foreslår kommisjonen å heve promillegrensen til $0,5 .{ }^{246}$ Det kan være delte meninger om promillegrensen bør være 0,5 eller 0,2 . Så lenge man opprettholder den strenge praksis med inndragning av førerkort, tviler jeg på at kjøring med lavpromille blir ufarliggjort. Det er imidlertid god grunn til å evaluere om senkingen av promillegrensen har hatt noen effekt når denne har vært virksom noen år. Så lenge det ikke foreligger noen slik evaluering, virker kommisjonens forslag noe bakstreversk.

I tilknytning til revisjonen av sedelighetsforbrytelsene ved lov av 11. august $2000 \mathrm{nr}$. 76, ble som nevnt grov uaktsom voldtekt kriminalisert, se strl. § 192 fjerde ledd. Til tross for at denne bestemmelsen bare hadde vært virksom i vel 19 måneder da kommisjonen avga sin innstilling, foreslår den å oppheve strl. $\S 192$ fjerde ledd. Kommisjonen anfører at i praksis vil en slik bestemmelse ramme et svært lite sjikt av overtredelser. Dertil vises det til at det ikke finnes noen tilsvarende bestemmelse i de øvrige nordiske land. ${ }^{247}$ Det kan nok reises spørsmål om en kriminalisering av grov uaktsom voldtekt gir bedre rettsvern mot å bli utsatt for overgrep. ${ }^{248}$ Men i visse tilfeller hvor det ikke kan føres bevis for at det foreligger forsett mht. til den objektive gjerningsbeskrivelse, kan det etter omstendighetene foreligge grov uaktsomhet i så måte. ${ }^{249}$ Det foreligger i hvert fall en underrettsavgjørelse hvor det er domfelt etter strl. § 192 fjerde ledd. I forhold til en så ny bestemmelse er det derfor all grunn til å avvente erfaringer før man foreslår å oppheve den. ${ }^{250}$

\section{Avslutning}

I en tid hvor man opplever at politikere stadig fremsetter krav om mer kriminalisering og strengere straffer, er Straffelovkommisjonens utredning et viktig dokument i motsatt retning. Jeg er kritisk til en del av de forslag som er fremsatt, men samlet sett kan utredningen bidra til at man kan bevare det humane preg i vår strafferettspleie, samtidig som straffenivået ikke presses opp i den politisk overbudspolitikk som vi i dag ser. ${ }^{251}$

Generelt sett savner jeg imidlertid at kommisjonen hadde satt reformen inn i en større ramme hvor man i større grad orienterte seg mot reguleringen og utviklingen $i$ andre lands strafferett. Rett nok er det en god del henvisninger til reguleringen $\mathrm{i}$ våre nordiske naboland, men det kunne nok vært grunn til også å rette blikket utenfor Norden. ${ }^{252}$ Særlig synes jeg fraværet av tysk rett er påfallende. ${ }^{253} \mathrm{I}$ det hele finner man en helt annen orientering mot fremmed rett $i$ forarbeidene til straffeloven av 1902 enn det som er tilfellet med utredningen fra 2002.

Utredningen er som nevnt et godt utgangspunkt for det videre arbeidet med den spesielle del. Det er grunn til å håpe at lovgivningsprosessen kan sluttføres slik at man får en ny straffelov før det er gått 30 år fra arbeidet ble iverksatt. 
Konvensjoner og lover med forkortelse:

BrB - Brotsbalken. Given Stockholms Slott den 21 december 1962.

dstrl. - Straffeloven af 15. april $1930 \mathrm{nr} .126$ med senere ændringer.

EMK - Europarådets konvensjon av 4. november 1950 om beskyttelse av menneskerettighetene og de grunnleggende friheter. (Den europeiske menneskerettighetskonvensjon).

Grl. - Kongeriget Norges Grundlov (Grunnloven), given i Rigsforsamlingen paa Eidsvold den 17de Mai 1814.

strl. - Almindelig borgerlig Straffelov (Straffeloven) av 22. mai $1902 \mathrm{nr} .10$.

strpl. - Lov om rettergangsmåten i straffesaker (Straffeprosessloven) av 22. mai 1981 nr. 25.

vpl. - Lov om skytevåpen og ammunisjon mv. av 9. juni $1961 \mathrm{nr} .1$.

vtrl. - Vegtrafikklov av 18. juni 1965 nr. 4.

\section{Lovforarbeider:}

Innstilling 1969 - Innstilling om rettergangsmåten i straffesaker fra Straffeprosesslovkomitéen. Avgitt i juni 1969.

Innst. O. nr. 37 (1980-81) - Innstilling frå justiskomitéen om rettergangsmåten i straffesaker (Straffeprosessloven).

Innst. O. nr. 34 (1996-97) - Innstilling fra justiskomiteen om lov om endringer i straffeloven m.v. (strafferettslige utilregnelighetsregler og særreaksjoner).

Innst. O. nr. 92 (1999-2000) - Innstilling fra justiskomiteen om lov om endringer i straffeloven m.v. (seksuallovbrudd).

NOU 1974: 17 - Strafferettslig utilregnelighet og strafferettslige særreaksjoner.

NOU 1983: 57 - Straffelovgivningen under omforming. Straffelovkommisjonens delutredning I.

NOU 1984: 31 - Straffelovgivningens stedlige virkeområde. Straffelovkommisjonens delutredning II.

NOU 1989: 11 - Straffansvar for foretak. Straffelovkommisjonens delutredning III.

NOU 1990: 5 - Strafferettslige utilregnelighetsregler og særreaksjoner. Straffelovkommisjonens delutredning IV.

NOU 1992: 23 - Ny straffelov - alminnelige bestemmelser. Straffelovkommisjonens delutredning V.

NOU 1995: 10 - Reformer innen injurielovgivningen.

NOU 1997: 23 - Seksuallovbrudd. Straffelovkommisjonens delutredning VI.

NOU 2002: 4 - Ny straffelov. Straffelovkommisjonens delutredning VII.

NOU 2003: 15 - Fra bot til bedring.

NOU 2003: 18 - Rikets sikkerhet. Straffelovkommisjonens delutredning VIII.

Ot.prp. nr. 35 (1978-79) - Om lov om rettergangsmåten i straffesaker (straffesakloven).

Ot.prp. nr. 62 (1980-81) - Om lov om endring i straffeloven m m (reglene om betinget dømte, prøveløslatelse $\mathrm{m} \mathrm{m}$, heving av strafferammen for grove narkotikalovbrudd, oppheving av livstidsstraffen).

Ot.prp. nr. 27 (1990-91) - Om lov om endringer i straffeloven m.m. (straffansvar for foretak).

Ot.prp. nr. 87 (1993-94) - Om lov om endringer i straffeloven $\mathrm{m} v$ (strafferettslig utilregnelighetsregler og særreaksjoner).

Ot.prp. nr. 8 (1998-99) - Om lov om endringer i straffeloven og straffeprosessloven mv (inndragning av utbytte).

Ot.prp. nr. 28 (1999-2000) - Om lov om endringer i straffeloven mv. (seksuallovbrudd).

Ot.prp. nr. 46 (2000-2001) - Om lov om endringer i straffeloven og i enkelte andre lover (endring og ikraftsetting av strafferettslige utilregnelighetsregler og særreaksjoner samt endringer i straffeloven $\S \S 238$ og 239).

Ot.prp. nr. 62 (2002-2003) - Om lov om endringer i straffeloven og straffeprosessloven mv. (lovtiltak mot organisert kriminalitet og menneskehandel, gjengangerstraff mv.).

Ot.prp. nr. 98 (2002-2003) - Om lov om endringer i straffeprosessloven (utvidelse av politijuristenes påtalekompetanse mv.).

St.meld. nr. 104 (1977-78) - Om kriminalpolitikken. 


\section{Litteratur:}

Andences 1997 - Andenæs, Johs.: Alminnelig strafferett. 4. utgave. Oslo 1997.

Andences LoR 1993 - Andenæs, Johs.: Dødshjelp og straffelov. LoR 1993 s. 144-146.

Andences TfS 2002- Andenæs, Johs.: Straffelovkommisjonens innstilling om ny straffelov. TfS 2002 s. $162-167$.

Andorsen 1999 - Andorsen, Kjell V.: Strafferettslig nødrett. Oslo 1999.

Andorsen LoR 2000 - Andorsen, Kjell V.: Aktiv dødshjelp og Høyesterett. LoR 2000 s. 321-322.

Andorsen TfS 2002 - Andorsen, Kjell V.: Straffelovkommisjonens innstilling om rettsvillfarelse. TfS 2002 s. 168-176.

Asbjørnsen 1995 - Asbjørnsen, Rasmus: Straffansvar for foretak ( str. paragraf 48 a. Norges forskningsråd. Rapport nr. 21. Oslo 1995.

Borvik TfR 2003 - Borvik, Bjørnar: EMK artikkel 8 og vernet mot ærekrenkingar. TfR 2003 s. 246-307.

Christie TfS 2002 - Christie, Nils: Epilog. TfS 2002 s. 396-397.

Garde/Strandbakken LoR 2001 - Garde, Peter og Strandbakken, Asbjørn: Juryen: Avskaffe, reformere eller begrense bruken av den? LoR 2001 s. 3-31.

Greve 1999 - Vagn, Greve: Det strafferetlige ansvar. København 1999.

Greve FS-Thornstedt - Greve, Vagn: Bør forsæt være en almindelig strafbarhedsbetingelse? Festskrift till Hans Thornstedt. Stockholm 1983 s. 229-248.

Harlem TfS 2003 - Harlem, Mads: Straffelovkommisjonens forslag til nytt kapittel 16 om krigsforbrytelser, folkemord og forbrytelser mot menneskeheten. TfS 2003 s. 238-250.

Hauge TfS 2002 - Hauge, Ragnar: Straffelovgivninges utvikling gjennom 100 år. TfS 2002 s. 338344.

Heffermehl TfS 2002 - Heffermehl, Andreas: Straffelovkommisjonens delutredning VII. TfS 2002 s. $135-161$.

Husabø 1994 - Husabø, Erling Johannes: Rett til sjølvvalt livsavslutning? Bergen 1994.

Husabø 1999 - Husabø, Erling Johannes: Straffansvarets periferi. Medverking, forsøk, førebuing. Bergen 1999.

Høgetveit TfS 2002 - Høgetveit, Einar: Hovedlinjer i Straffelovkommisjonens utkast til ny straffelov. TfS 2002 s. 360-370.

Johnsen TfS 2003 - Johnsen, Jon. T.: Upartisk straffeforfølgning - ramme for fornærmedes rettigheter i straffesaker? TfS 2003 s. 141-165.

Matningsdal FS-Smith - Matningdal, Magnus: Hvordan kan Stortinget påvirke straffenivået? Rettsteori og rettsliv. Festskrift til Carsten Smith. Oslo 2002 s. 569-588.

Matningsdal LoR 1993 - Matningsdal, Magnus: Nyere reaksjonspraksis m.v. ved promillekjøring og etterfølgende alkoholnytelse. LoR 1993 s. 151-180.

Matningsdal TfS 2002 - Matningsdal, Magnus: Høyesteretts rolle i utviklingen av strafferetten. TfS 2002 s. 345-359.

Matningsdal/Bratholm 2003 I - Matningsdal, Magnus og Bratholm, Anders (red.): Straffeloven med kommentarer. Første Del. Almindelige Bestemmelser. 2. utgave. Oslo 2003.

Matningsdal/Schneider JV 1989 - Matningsdal, Magnus og Schneider, Gudrun: Juridiske personers straffansvar. JV 1989 s. 49-104.

Matningsdal JV 1996 - Matningsdal, Magnus: Straffansvar for foretak. JV 1996 s. 98-115.

Matningsdal/Strandbakken FS-Jareborg - Matningsdal, Magnus og Strandbakken, Asbjørn: Straffenivå og straffeteorier i norsk strafferett anno 2001. Flores juris et legum. Festskrift till Nils Jareborg. Uppsala 2002 s. 481-502.

Mceland 1999 - Mæland, Henry John: Innføring i alminnelig strafferett. 2. utgave. Bergen 1999.

Mceland TfS 2002 - Mæland, Henry John: Fra Kriminalloven til straffeloven. TfS 2002 s. 326-337.

Rieber-Mohn JK 4/2003 - Rieber-Mohn, Georg Fr.: Forvaring - en strafferettslig særreaksjon. JK $4 / 2003$ s. $36-40$.

Rieber-Mohn JK 5/2003 - Rieber-Mohn, Georg Fr.: Forvaring som strafferettslig særreaksjon (II). JK 5/2003 s. 35-39. 
Slettan TfS 2002 - Slettan, Svein: Hva er passe straff? TfS 2002 s. 379-386.

Slettan/Øie 1997 - Slettan, Svein og Øie, Toril M.: Forbrytelse og straff. Lærebok i strafferett. Oslo 1997. Strandbakken 1989 - Strandbakken. Asbjørn: Senkingen av minstestraffen. Bruken av fengsel under 21 dager og straffelovens paragraf 26a. Det juridiske fakultets skriftserie nr. 19. Universitetet i Bergen 1989.

Strandbakken 2003 - Strandbakken, Asbjørn: Uskyldspresumsjonen - «In dubio pro reo». Bergen 2003. Strandbakken JV 1997 - Strandbakken, Asbjørn: Klage over påtalevedtak. JV 1997 s. 127-167.

Toftegaard Nielsen/Strandbakken/Träskman NTfK 2003 - Toftegaard Nielsen, Gorm, Strandbakken, Asbjørn og Träskman, Per Ole: Om selskabsansvar i Norden. NTfK 2003 s. 1-27.

Torgersen/Engstrøm 1998 - Torgersen, R. N. og Engstrøm, Bjørn: Vegtrafikkloven og trafikkreglene med kommentarer. 3. utgave. Oslo 1998

\section{Noter}

${ }^{2}$ Se nærmere Matningsdal/Strandbakken FS-Jareborg s. 483 flg.

3 Utredningen er utlagt på internett under følgende adresse: http://www.odin.dep.no/jd/norsk/publ/utredninger/NOU/012001-020017/index-dok000-b-n-a.html

${ }^{4}$ Forslaget er også omtalt hos Heffermehl TfS 2002 s. 135-161 og Høgetveit TfS 2002 s. 360-370. Deler av innstillingen er dessuten kommentert av Andenaes TfS 2002 s. 162-167, Andorsen TfS 2002 s. $168-176$ og Harlem TfS 2003 s. 238-250.

${ }^{5}$ Se St.meld. nr. 104 (1977-78) s. 96 første spalte.

${ }^{6}$ Om kriminalloven og utviklingen frem mot strafferettsreformen av 1902, se Mceland TfS 2002 s. 326-337. Om utviklingen og de kriminalpolitiske standpunkter som har preget diskusjonen under straffeloven av 1902, se Hauge TfS 2002 s. 338-344.

${ }^{7}$ Se St.meld. nr. 104 (1977-78) s. 96 første spalte.

${ }^{8}$ St.meld. nr. 104 (1977-78) s. 96 andre spalte.

${ }^{9}$ St.meld. nr. 104 (1977-78) s. 97 første spalte.

${ }^{10}$ Se NOU 1983: 57 s. 28-29.

"Se NOU 1983: 57 s. 31 andre spalte.

${ }^{12}$ Se nærmere Strandbakken 1989 s. 3-9.

${ }^{13}$ Se nærmere Strandbakken JV 1997 s. 127-167.

${ }^{14}$ Se NOU 1992: 23 s. 34 første spalte.

${ }^{15}$ Se oversikten hos Matningsdal/Bratholm 2003 I s. 34, s. 68 og s. 73.

${ }^{16}$ Se nærmere NOU 1989: 11 s. 8 jfr. s. 48 hvor de to fraksjoners lovutkast er inntatt.

${ }^{17}$ Se Ot.prp. nr. 27 (1990-1991) s. 11-12. Nærmere om foretaksstraffen, se Matningsdal/Bratholm $2003 I$ s. 390 flg. Se også Asbjørnsen 1995, Matningsdal JV 1996 s. 98-115 og Toftegaard Nielsen/Strandbakken/Träskman NTfK 2003 s. 4-14.

${ }^{18}$ Se NOU 1992: 23 s. 280 første spalte.

${ }^{19}$ Se NOU 2002: 4 s. 477 første spalte.

${ }^{20}$ Se NOU 1990: 5 s. 7 første spalte.

${ }^{21}$ Se utkastet til strl. $§ 45$ i NOU 1990: 5 s. 9 andre spalte.

${ }^{22}$ Se NOU 1990: 5 s. $15-17$ jfr. utkastet til ny strl. $\S 39$ og 39 a i NOU 1990: 5 s. 8.

${ }^{23}$ Se NOU 1990: 5 s. 17-19 jfr. utkastet til ny strl. § 39 c i NOU 1990: 5 s. 8-9.

${ }^{24}$ Se Ot.prp. nr. 87 (1993-94).

${ }^{25}$ Se Innst. O. nr. 34 (1996-97).

${ }^{26}$ Nærmere om særreaksjonene, se Matningsdal/Bratholm 2003 I s. 288 flg., Rieber-Mohn JK 4/2003 s. 36-40 og Rieber-Mohn JK 5/2003 s. 35-39.

${ }^{27}$ Se nærmere Ot.prp. nr. 46 (2001-2002).

${ }^{28}$ Se NOU 1992: 23 s. 20-21.

${ }^{29}$ Se NOU 2002: 4 s. 34 andre spalte.

${ }^{30}$ Se nærmere NOU 1992: 23 s. 19.

${ }^{31}$ Se NOU 2002: 4 s. 33-34.

${ }^{32}$ Se nærmere NOU 1997: 23 s. 10-12 som gir et sammendrag av utvalgets forslag. 
${ }^{33}$ Straffelovkommisjonen av 1994 er skeptisk til en generell kriminalisering av kjøp av seksuelle tjenester, men foreslår å videreføre forbudet mot kjøp av seksuelle tjenester av personer under 18 år, se skissen til § 28-15 jfr. NOU 2002: 4 s. 364.

${ }^{34}$ Se nærmere Ot.prp. nr. 28 (1999-2000) s. 7-8.

${ }^{35}$ Se nærmere Innst. O. nr. 92 (1999-2000) s. 11-14 og s. 19-22.

${ }^{36}$ Om oppbyggingen av kapittelskissene, se NOU 2002: 4 s. 274-275.

${ }^{37}$ Se NOU 2002: 4 s. 36.

${ }^{38}$ Se nærmere NOU 2002: 4 s. 36-37.

${ }^{39}$ Se nærmere NOU 2003: 18 s. 12-13 hvor utvalgets mandat er inntatt.

${ }^{40}$ Se NOU 2003: 18 s. 155-156.

${ }^{41}$ Se NOU 2003: 18 s. 71-72.

${ }^{42}$ Se NOU 1983: 57 s. 29 første spalte.

${ }^{43}$ Se NOU 2002: 4 s. 78 første spalte jfr. s. 38-39 og s. 33-34.

${ }^{44}$ Se NOU 2002: 4 s. 78 første spalte.

${ }^{45}$ Se NOU 2002: 4 s. 78 andre spalte.

${ }^{46}$ Se NOU 2002: 4 s. 78-79.

${ }^{47}$ Se NOU 2002: 4 s. 79.

${ }^{48}$ Se nærmere NOU 2002: 4 s. 80 jfr. s. 408-409.

${ }^{49}$ Se NOU 2002: 4 s. 80 andre spalte.

${ }^{50}$ Se nærmere NOU 2002: 4 s. 81 første spalte.

${ }^{51}$ Se NOU 2002: 4 s. 81 andre spalte.

${ }^{52}$ Se nærmere NOU 2002: 4 s. 82.

${ }^{53}$ Se NOU 2002: 4 s. 82-83.

${ }^{54}$ Se nærmere NOU 2002: 4 s. 83-84.

${ }^{55}$ Se NOU 2002: 4 s. 84 første spalte.

${ }^{56}$ Se nærmere NOU 2002: 4 s. 84 første spalte jfr. s. 342-344 og s. 439 flg.

${ }^{57}$ Se for øvrig også Rt. 2002 s. 509 som er avsagt etter at kommisjonen avleverte sin innstilling, hvor også ileggelse av $30 \%$ tilleggsskatt ble ansett som «a criminal charge» etter EMK artikkel 6 (1).

${ }^{58}$ Se NOU 2002: 4 s. 85 første spalte.

${ }^{59}$ Se NOU 2002: 4 s. 85 andre spalte.

${ }^{60}$ Se NOU 2002: 4 s. 86.

${ }^{61}$ Se NOU 2002: 4 s. 85 første spalte.

${ }^{62}$ Se NOU 1983: 57 s. 146-147.

${ }^{63}$ Se NOU 2002: 4 s. 87 første spalte.

${ }^{64}$ Se NOU 2002: 4 s. 87 andre spalte.

${ }^{65}$ Se NOU 2002: 4 s. 89 første spalte.

${ }^{66}$ Se NOU 2002: 4 s. 335

${ }^{67}$ Se NOU 2002: 4 s. 89.

${ }^{68}$ Se NOU 2002: 4 s. 90 første spalte.

${ }^{69}$ Se NOU 2002: 4 s. 290 første spalte.

${ }^{70}$ Se NOU 2002: 4 s. 334 andre spalte.

${ }^{7}$ Se NOU 2002: 4 s. 90 første spalte jfr. s. 283-284. Lundutvalget har ikke fulgt opp dette forslaget, men har i stedet valgt å kriminalisere det å volde fare for de verdier som straffebudet tar sikte på å verne, se NOU 2003: 18 s. 79.

${ }^{72}$ Se også strl. § 147 a tredje ledd som rammer det å inngå forbund om å begå terrorhandling som nevnt i $\S 147$ a første ledd.

${ }^{73}$ Se NOU 1983: 57 s. 134 og NOU 1992: 23 s. 81.

${ }^{74}$ Se NOU 2002: 4 s. 90-91. En sammenfatning av betenkningen er inntatt i NOU 2002: 4 s. 91-98.

Betenkningen er i sin helhet trykket i Husabø 1999 s. 301-386.

${ }^{75}$ Se nærmere NOU 2002: 4 s. 92.

${ }^{76}$ Se NOU 2002: 4 s. 93-94.

${ }^{77}$ Se NOU 2002: 4 s. 95 jfr. s. 96-97. 
${ }^{78}$ Se NOU 2002: 4 s. 95-96.

${ }^{79}$ Se nærmere Strandbakken 2003 s. 388-390.

${ }^{80}$ Se nærmere NOU 2002: 4 s. 96.

${ }^{81}$ Se nærmere opplistingen i NOU 2002: 4 s. 98 andre spalte.

${ }^{82}$ Se NOU 2002: 4 s. 98 andre spalte jfr. s. 303-305.

${ }^{83}$ For så vidt gjelder straffansvar for forberedelseshandlinger og forsøk, slutter Lundutvalget seg til kommisjonens generelle synspunkter, se NOU 2003: 18 s. 78-80.

${ }^{84}$ Se Lundutvalget, NOU 2003: 18 s. 118 første spalte, som fremhever at skjult økonomisk støtte til politiske partier kan være moralsk betenkelig, men at dette ikke er tilstrekkelig til å kriminalisere handlingen.

${ }^{85}$ Se NOU 2002: 4 s. 331 første spalte.

${ }^{86}$ Se nærmere reportasjen i VG 23. august 2003 s. 42-44: «Tragedien vi er blitt blinde for». Se også Dagbladet 25. august 2003 s. 10-12.

${ }^{87}$ Se NOU 2002: 4 s. 331 første spalte.

${ }^{88}$ Se nærmere NOU 2002: 4 s. 349-352.

${ }^{89}$ Se NOU 2002: 4 s. 352.

${ }^{90}$ Se NOU 2002: 4 s. 351 jfr. 216-217.

91 Se Andenas LoR 1993 s. 144-146, Andorsen 1999 særlig s. 306 flg. og Andorsen LoR 2000 s. 321-322.

${ }_{92}$ Se for øvrig Pretty v. The United Kingdom, Application no. 2346/02, Judgment of $29^{\text {th }}$ April 2002 hvor det ble lagt til grunn at man ikke kunne utlede noen rett til «assisted suicide» av EMK artikkel 2. En slik rett kunne heller ikke utledes av artikkel 3. Domstolen holdt det åpen om en rett til selv å kunne avslutte livet var vernet under artikkel 8 (1), men fant uansett at statens inngrep var legitimert under artikkel 8 (2). Det forelå heller ingen krenkelse av artikkel 9 eller 14.

${ }^{93} \mathrm{Sml}$. Lundutvalget som deler kommisjonens syn på spørsmålet om kriminalisering av uaktsomme handlinger, se NOU 2003: 18 s. 107 første spalte.

${ }^{94}$ Se nærmere Strandbakken 2003 s. 619-621.

${ }^{95} \mathrm{Sml}$. NOU 1992: $23 \mathrm{~s}$. 118 vedrørende diskusjonen om å beholde skyldformen dolus eventualis.

${ }^{96}$ Se nærmere Ot.prp. nr. 62 (2002-2003) s. 7-8.

${ }^{97}$ Se NOU 2002: 4 s. 33 andre spalte.

${ }^{98}$ Se NOU 2002: 4 s. 100. Torgersens utredning er inntatt i NOU 2002: 4 s. 100-143.

${ }^{99}$ Se NOU 2002: 4 s. 143 første spalte.

${ }^{100}$ Se NOU 2002: 4 s. 143 andre spalte.

${ }^{101}$ Se NOU 2002: 4 s. 143 andre spalte.

${ }^{102}$ Om straffutmåling ved promillekjøring, se Matningsdal LoR 1993 s. 151-180 og Matningsdal i Togersen/Engstrøm 1998 s. 423-454.

${ }^{103}$ Kommisjonen foreslår således at vtrl. $\S 31$ andre til fjerde ledd om retningslinjer for straffutmålingen ved promillekjøring oppheves, se NOU 2002: 4 s. 457 andre spalte.

${ }^{104}$ Se NOU 2002: 4 s. 144 første spalte.

${ }^{105}$ NOU 2002: 4 s. 144 andre spalte.

${ }^{106}$ Se NOU 2002: 4 s. 145 første spalte.

${ }^{107}$ Se NOU 2002: 4 s. 145.

${ }^{108}$ NOU 2002: 4 s. $145-146$.

${ }^{109}$ Se NOU 2002: 4 s. 146-147.

${ }^{110}$ Se nærmere NOU 2002: 4 s. 300 andre spalte.

"I' Se NOU 2002: 4 s. 147-148. Se som eksempel skissen til $\S \S 25-15-25-17$ som omhandler ulovlig befatning med plutonium og uran, samt bakteriologiske og kjemiske våpen, se nærmere NOU 2002: 4 s. 330 andre spalte jfr. s. 336 andre spalte.

${ }^{112}$ Se NOU 2002: 4 s. 148 første spalte.

${ }^{113}$ Se NOU 2002: 4 s. 148 andre spalte.

${ }^{114}$ Se NOU 2002: 4 s. 148-149.

${ }^{115}$ Se nærmere NOU 2002: 4 s. 149 jfr. s. 361 andre spalte. 
${ }^{116}$ Se NOU 2002: 4 s. 149 andre spalte jfr. s. 372 første spalte.

${ }^{117}$ Se nærmere NOU 2002: 4 s. 149-150.

${ }^{118}$ Se NOU 2002: 4 s. 360 første spalte.

${ }^{119}$ Se NOU 2002: 4 s. 366 første spalte.

${ }^{120}$ Se NOU 2002: 4 s. 150.

${ }^{121}$ Se NOU 2002: 4 s. 150-151.

${ }^{122}$ Se nærmere NOU 2002: 4 s. 152 andre spalte.

${ }^{123}$ Se NOU 2002: 4 s. 153 første spalte.

${ }^{124}$ Se nærmere NOU 2002: 4 s. 153-154.

${ }^{125}$ Se NOU 2002: 4 s. 154 første spalte.

${ }^{126}$ Se nærmere NOU 2002: 154. Om andre tilfeller hvor det er foreslått felles strafferamme, se NOU 2002: 4 s. 154-155.

${ }^{127}$ Se nærmere NOU 2002: 4 s. 464. Slik også Lundutvalget i NOU 2003: 18 s. 143 andre spalte.

${ }^{128}$ Se nærmere NOU 2002: 4 s. 155-156 jfr. s. 214 andre spalte.

${ }^{129}$ Se NOU 2002: 4 s. 156 andre spalte.

${ }^{130}$ Se NOU 2002: 4 s. 156-157.

${ }^{13 !}$ Se nærmere NOU 2002: 4 s. 157.

${ }_{132}^{13}$ Se nærmere NOU 2002: 4 s. 157.

${ }^{133}$ Se NOU 2002: 4 s. 157 andre spalte.

${ }^{134}$ Se Ot.prp. nr. 62 (2002-2003) s. 94 andre spalte.

${ }^{135}$ Se Ot.prp. nr. 62 (2002-2003) s. 81 første spalte.

${ }^{136} \mathrm{Om}$ de prosessuelle implikasjoner dette kan føre til mht. bruk av jury, se Garde/Strandbakken LoR 2001 s. 24-26.

${ }^{137}$ Se også Lundutvalget som slutter seg til det strafferammesystemet som kommisjonen har foreslått, se NOU 2003: 18 s. 82 andre spalte.

${ }^{138}$ Se bl.a. Matningsdal FS-Smith s. 569-588 som gir en utførlig fremstilling av hvordan lovgiver har vurdert spørsmålet, herunder drøfter på hvilken måte Stortinget kan påvirke straffenivået.

${ }^{139}$ Se nærmere Matningsdal FS-Smith s. 573-576 som redegjøre for eksempler på både fastsettelse og opphevelse av bestemmelser om minstestraff.

${ }^{140}$ Se nærmere Matningsdal FS-Smith s. 576-579.

${ }^{141}$ Matningsdal FS-Smith s. 578 jfr. s. 584 uttaler at det ville være illojalt overfor lovgiver om en endring i strafferammen ikke hadde avspeilt seg i straffenivået.

${ }^{142}$ Se Matningsdal FS-Smith s. 579-580.

${ }^{143}$ Slik Matningsdal FS-Smith s. 581-583.

${ }^{144}$ Se Matningsdal FS-Smith s. 583 som er kritisk til å legge vekt på politiske signaler fordi dette kan medføre en politisk overstyring av domstolene.

${ }^{145}$ Slik også Matningsdal TfS 2002 s. 357. Se for øvrig Matningsdal TfS 2002 s. 346 som treffende beskriver samspillet mellom lovgiver og domstolene som et stafettløp. Se også Matningsdal TfS 2002 s. 354 hvor det uttales at samspillet mellom lovgiver og domstoler forutsetter at domstolene legger vekt på forarbeidene.

${ }^{146}$ Se Matningsdal FS-Smith s. 583.

${ }^{147}$ Slik også Matningsdal TfS 2002 s. 358-359.

${ }^{148}$ Se Matningsdal TfS 2002 s. 359.

${ }^{149}$ Slik også Slettan TfS 2002 s. 386.

${ }^{150}$ Se nærmere NOU 2002: 4 s. 337.

${ }^{151}$ Andences TfS 2002 s. 164 håper at kommisjonens nøkterne forslag slår igjennom overfor den panikkartede reaksjon overfor narkotikaforbrytelser som ellers har dominert i den offentlige diskusjonen.

${ }^{152}$ Sml. Slettan TfS 2002 s. 383 som fremhever at det alminnelige straffenivå i narkotikasaker er alt for høyt, men fremhever at enkelte narkotikasaker kan være så grove at det kanskje i unntakstilfeller bør være rom for å idømme 21 års fengsel.

${ }^{153}$ Slik også Lundutvalget i NOU 2003: 18 s. 86 andre spalte. 
${ }^{154}$ Sml. Slettan TfS 2002 s. 383 som synes å være enig med mindretallet.

${ }^{155}$ Se NOU 2002: 4 s. 236 første spalte.

${ }^{156}$ Se tabellen inntatt i NOU 2002: 4 s. 236.

${ }^{157}$ Slik også Slettan TfS 2002 s. 382.

${ }^{158}$ Slettan TfS 2002 s. 379-382 erkjenner at det neppe spiller noen rolle om straffen er 15, 21 eller 30 år, men støtter likevel forslaget om å heve maksimumsstraffen ut fra at lovbryteren skal ha straff som fortjent og at de groveste forbrytelser fortjener strengere straff.

${ }^{159}$ Se nærmere Ot.prp. nr. 62 (1980-81) s. 30-31.

${ }^{160}$ Se NOU 2002: 4 s. 153 første spalte.

${ }^{161}$ Slettan TfS 2002 s. 383 fremhever imidlertid at strafferammene må ta høyde for spennvidden i straffverdigheten slik at de også oppfanger ekstraordinære tilfeller som det kan gå år mellom hver gang man ser.

${ }^{162}$ Se NOU 2002: 4 s. 337 andre spalte som beskriver denne utviklingen.

${ }^{163}$ Se NOU 2003: 18 s. 86 første spalte.

${ }^{164}$ Se nærmere NOU 2002: 4 s. 158 første spalte jfr. s. 70 flg.

${ }^{165}$ Se NOU 2002: 4 s. 158 andre spalte.

${ }^{166}$ Se NOU 2002: 4 s. 159 første spalte.

${ }^{167}$ Se NOU 2002: 4 s. 159 andre spalte jfr. s. $430-434$, s. 436 og s. 437.

${ }^{168}$ Se bl.a. NOU 1983: 57 s. 77 andre spalte.

${ }^{169}$ Se NOU 2002: 4 s. 160.

${ }^{170}$ Se NOU 2002: 4 s. 436-437.

${ }^{17}$ Se NOU 2002: 4 s. 160-161.

${ }^{172}$ I NOU 1983: 57 s. 77 første spalte ble det antatt at straffebud inntatt i straffeloven blir bedre kjent.

${ }^{173}$ Se NOU 2002: 4 s. 161-162.

${ }^{174}$ Bestemmelsen om promillekjøring og etterfølgende alkoholnytelse - skissen til $\S \S 25-8$ og 25-9

- er til tross for dette foreslått overført til straffeloven fordi bestemmelsene praktiseres relativt strengt, se nærmere NOU 2002: 4 s. 434-435. På den andre siden er strl. § 245 om avbrytelse av svangerskap på grunn av den saklige sammenhengen foreslått overført til abortloven av 13. juni $1975 \mathrm{nr}$. 50, se NOU 2002: 4 s. 438. Se også forslaget om at alle bestemmelser om straffbare forhold i sjøfartsforhold samles i spesiallovgivningen, jfr. NOU 2002: 4 s. 442-446.

${ }^{175}$ Se NOU 2002: 4 s. 162 andre spalte.

${ }^{176}$ Se NOU 2002: 4 s. 163 første spalte.

${ }^{177}$ Som eksempel kan det også vises til reglene om foretaksstraff slik de lød før endringen i 1991, se nærmere Matningsdal/Schneider JV 1989 s. 49 flg.

${ }^{178}$ Se nærmere NOU 2002: 4 s. 163-164 jfr. s. 320-321 og s. 429-430 for så vidt gjelder skissen til $\S 23-1$ om brudd på taushetsplikt.

${ }^{179}$ Se St.meld. nr. 104 (1977-78) s. 168 første spalte hvor det er anført et slikt synspunkt.

${ }^{180}$ Slik også Christie TfS 2002 s. 396 og Hauge TfS 2002 s. 341-344.

${ }^{181}$ Se NOU 2002: 4 s. 164 andre spalte.

${ }^{182}$ Se nærmere NOU 2002: 4 s. 447-448.

${ }^{183}$ Se NOU 2002: 4 s. 165.

${ }^{184}$ Se nærmere NOU 2002: 4 s. 166.

${ }^{185}$ Se nærmere NOU 2002: 4 s. 166-167.

${ }^{186}$ Se NOU 2002: 4 s. 167-168.

${ }^{187}$ Se for øvrig NOU 2002: 4 s. 169-170 hvor Straffelovkommisjonen gjennomgår eksempler på avvikende formuleringer av uaktsomhetskravet, og s. $170 \mathrm{om}$ variasjoner av kravet til forsett.

${ }^{188}$ Se NOU 2002: 4 s. 168-169. Lundutvalget slutter seg til dette utgangspunktet, se NOU 2003: 18 s. 82 første spalte. Kommisjonen gir imidlertid flere eksempler på hvor hensiktskravet bør beholdes, se NOU 2002: 4 s. 177 første spalte jfr. s. 297 som bl.a. fremhever strl. § 134 første ledd om å lemleste seg selv i hensikt å unndra seg militærtjeneste, og etter skissen til grovt drap - §27-6 - er det forutsatt at et moment for vurderingen av om handling er grov skal være om drapet er skjedd $\mathrm{i}$ hensikt å skjule en annen overtredelse, se NOU 2002: 4 s. 348. 
${ }^{189}$ Se NOU 2002: 4 s. 171-172. Om andre straffebud hvor hensiktskravet har betydning, se NOU 2002: 4 s. $176-177$.

${ }^{190}$ Se NOU 2002: 4 s. 175-176. Sml. Lundutvalget som fremhever at dersom det bare er gjerningspersonens hensikt som gjør forberedelseshandlingen straffverdig, bør den bare kriminaliseres hvor det kan påvises at dette vil bidra til et effektivt vern om den interesse det er tale om, se NOU 2003: 18 s. 82.

${ }^{191}$ Se Andences 1997 s. 291, Mceland 1999 s. 115-116 og Slettan/Øie 1997 s. 202.

${ }^{192}$ Se NOU 2002: 4 s. 170-171. Se imidlertid utkastet til § 3-13 som medfører en viss justering av bestemmelsen om rettsvillfarelse.

${ }^{193}$ Se NOU 2002: 4 s. 173-175.

${ }^{194}$ Se NOU 2002: 4 s. 175.

${ }^{195}$ Se NOU 2002: 4 s. 177 første spalte jfr. s. 149 første spalte.

${ }^{196}$ Se NOU 2002: 4 s. 177.

${ }^{197}$ Se NOU 1992: 23 s. 121-122.

${ }^{198}$ Se NOU 2002: 4 s. 178-179 jfr. s. 476 første spalte.

${ }^{199}$ Se nærmere Matningsdal/Bratholm 2003 I s. 343-344.

${ }^{200}$ Se NOU 1983: 57 s. 146 første spalte jfr. s. 150 andre spalte.

${ }^{201}$ Se NOU 1992: 23 s. 115 første spalte.

${ }^{202}$ Se NOU 2002: 4 s. 225 første spalte. Andenaes TfS 2002 s. 165 finner flertallets argumentasjon overbevisende.

${ }^{203}$ Se også mindretallet i kommisjonen, lederen Høgetveit i NOU 2002: 4 s. 225. Om innskjerpingen av virkeområdet til dolus eventualis i forslaget fra 1991, se NOU 1992: 23 s. 118-119.

${ }^{204}$ Se eksemplene som kommisjonen av 1980 har fremhevet i NOU 1992: 23 s. 118.

${ }^{205}$ Se NOU 1992: 23 s. 118 andre spalte.

${ }^{206}$ Se også Rt. 2003 s. 118 hvor det forelå dolus eventualis når to heroinmisbrukere fikk kjøpt mer stoff enn de på forhånd hadde regnet med.

${ }^{207}$ Se nærmere Strandbakken 2003 s. 386.

${ }^{208}$ Se nærmere Andences 1997 s. 477-481, Mceland 1999 s. 225-226 og Slettan/Øie 1997 s. 219-221.

${ }^{209}$ Se NOU 2002: 4 s. 183 første spalte.

${ }^{210}$ Se NOU 2002: 4 s. 183 første spalte.

${ }^{211}$ Se NOU 2002: 4 s. 183 andre spalte.

${ }^{212}$ Se NOU 2002: 4 s. 183 andre spalte.

${ }^{213}$ Se NOU 2002: 4 s. $183-184$.

${ }^{214}$ Se NOU 2002: 4 s. 187.

${ }^{215}$ Se NOU 2002: 4 s. 184 første spalte.

${ }^{216}$ Se NOU 2002: 4 s. 186 første spalte.

${ }^{217}$ Se NOU 2002: 4 s. 184.

${ }^{218}$ Se nærmere NOU 2002: 4 s. 185-186. Unntak fra dette utgangspunktet finner man for eksempel i forhold til skissen til § 25-10 om påføring av smitte eller fare for smitte hvor det foreslås en strafferamme på 3 år, men slik at det likevel skal kreves påtalebegjæring fra fornærmede når gjerningspersonen er en av den fornærmedes nærmeste, se NOU 2002: 4 s. 335 andre spalte jfr. s. 338.

${ }^{219}$ Se NOU 2002: 4 s. 186-187.

${ }^{220}$ Se NOU 2002: 4 s. 185 første spalte.

${ }^{221}$ Se Innstilling 1969 s. 118-119.

${ }^{222}$ Se NOU 2002: 4 s. 188.

${ }^{223}$ Se Innstilling 1969 s. 119-120.

${ }^{224}$ Se Ot.prp. nr. 35 (1978-1979) s. 84-86 og Innst. O. nr. 37 (1980-1981) s. 11 første spalte.

${ }^{225}$ Se nærmere NOU 1995: 10 s. 58-60.

${ }^{226}$ Se NOU 1995: 10 s. 70-71.

${ }^{227}$ Se NOU 2002: 4 s. 191.

${ }^{228}$ Se NOU 2002: 4 s. 191-192.

${ }^{229}$ Se nærmere NOU 2002: 4 s. 192. 
${ }^{230}$ For så vidt gjelder spørsmålet om å delegere ytterligere påtalekompetanse til politinivået, se intervju med riksadvokat Tor Aksel Busch i JK 5/2003 s. 18-19 hvor det fremgår at han og andre på statsadvokatnivå er sterkt kritisk til forslaget i Ot.prp. nr. 98 (2002-2003). Se også Politiembetsmennes landsforenings høringsuttalelse som er inntatt i PEL 2/2003 s. 3. Kritikken imøtegås av statssekretær Jørn Holme i JK 6/2003 s. 30. Se også Hans Kristian Bjerke i JK 6/2003 s. 31-32 som anfører at betenkelighetene ved en eventuell overføring av påtalekompetanse til politiet, kan oppveies ved å innføre en form for rettslig kontroll med tiltalebeslutninger etter modell av den tyske «Zwischenverfahren».

${ }^{231}$ Se Johnsen TfS 2003 s. 141-165 som drøfter og vurderer et vidtgående forslag om å styrke fornærmedes innflytelse i straffeprosessen ut over de endringer som er gjennomført fra begynnelsen av 1990-årene frem til i dag.

${ }^{232}$ Se NOU 2002: 4 s. 342-344 jfr. s. 439 flg.

${ }^{233}$ Se blant annet forslaget om å innføre et skyldkrav mht. beskyldningens sannhet, jfr. NOU 2002: 4 s. 342-343.

${ }^{234}$ De aktuelle ærekrenkelsessaker hvor Norge er domfelt for krenkelse av EMK artikkel 10 er: Nilsen and Johnsen v. Norway, Application no. 23118/93, Judgment of $25^{\text {th }}$ November 1999, Bladet Tromsø A/S and Stensås v. Norway, Application no. 21980/93, Judgment of $20^{\text {th }}$ May 1999 og Bergens Tidende and others v. Norway, Application no. 26132/95. Judgment of $2^{\text {nd }}$ May 2000. Det bør også nevnes at flere saker om ærekrenkelse fra Norge, er blitt avvist i Strasbourg uten at disse er viet den samme oppmerksomhet i norske massemedia.

${ }^{235}$ Se nærmere Borvik TfR 2003 s. 246-307.

${ }^{236}$ Se punkt 2.5 ovenfor.

${ }^{237}$ Se nærmere NOU 2002: 4 s. 230.

${ }^{238}$ Mindretallet - Coward og Hauge - er imot forvaringsinstituttet, se NOU 2002: 4 s. 252 første spalte.

${ }^{239}$ Se NOU 2002: 4 s. 252-253.

${ }^{240}$ Se Ot.prp. nr. 46 (2000-2001) s. 31.

${ }^{241}$ Se Ot.prp. nr. 8 (1998-99) s. 29-30.

${ }^{242}$ Se NOU 2002: 4 s. 257 første spalte.

${ }^{243}$ Application no. 41087/98, Judgment of $5^{\text {th }}$ July 2001.

${ }^{244}$ Se NOU 2002: 4 s. 308-309.

${ }^{245}$ Se NOU 2002: 4 s. 333 andre spalte med henvisninger.

${ }^{246}$ Se NOU 2002: 4 s. 334 første spalte jfr. s. 80 andre spalte. Andenaes TfS 2002 s. 163 stiller seg positiv til dette forslaget.

${ }^{247}$ Se nærmere NOU 2002: 4 s. 405-406.

${ }^{248}$ Se Strandbakken 2003 s. 426-428.

${ }^{249}$ Se eksemplene omtalt hos Greve FS-Thornsted s. 232-234 og Greve 1999 s. 200.

${ }^{250}$ Se for øvrig NOU 2002: 4 s. 406 hvor det også foreslås å oppheve strl. § 207 som gir domstolene plikt til å vurdere om domfellelse for visse seksuallovbrudd skal medføre rettighetstap. Bestemmelsen kom inn i loven ved revisjonen av 11. august $2000 \mathrm{nr} .76$.

${ }^{251}$ Se Christie TfS 2002 s. 396 og Hauge TfS 2002 s. 343-344.

${ }^{252}$ Se imidlertid utredningen til Torgersen inntatt i NOU 2002: 4 s. 100-143 som drøfter strafferammer både $\mathrm{i}$ et nordisk og mer internasjonalt perspektiv.

${ }^{253}$ Utredningen til Husabø som er inntatt i NOU 2002: 4 s. 91-98 inneholder imidlertid redegjørelse for rettsstilstanden i flere sentrale land i Europa, bl.a. tysk, engelsk og nederlandsk rett.

Adresse: Det juridiske fakultet

Universitetet i Bergen, Dragefjellet

Magnus Lagabøts Plass 1

N-5010 Bergen

strandbakken@jur.uib.no 